\title{
Fibrin biopolymer as scaffold candidate to treat bone defects in rats
}

\author{
Claudia Vilalva Cassaro 1,2,* (D), Luis Antonio Justulin Jr. ${ }^{3}$, Patrícia Rodrigues de Lima ${ }^{1,2}$, Marjorie de Assis Golim4, \\ Natália Perussi Biscola ${ }^{1,5}$, Mateus Vidigal de Castro ${ }^{5}$ (D), Alexandre Leite Rodrigues de Oliveira ${ }^{5}$, Danuta Pulz \\ Doiche $^{6}$, Elenize Jamas Pereira ${ }^{1,2}$, Rui Seabra Ferreira Jr., ${ }^{1,2}$, Benedito Barraviera ${ }^{1,2}$ \\ ${ }^{1}$ Center for the Study of Venoms and Venomous Animals (CEVAP), São Paulo State University (UNESP), Botucatu, SP, Brazil. \\ 2 Botucatu Medical School (FMB), São Paulo State University (UNESP), Botucatu, SP, Brazil. \\ ${ }^{3}$ Extracellular Matrix Laboratory, Botucatu Biosciences Institute (IBB), São Paulo State University (UNESP), Botucatu, SP, Brazil. \\ ${ }^{4}$ Flow Cytometry Laboratory, Blood Center, Botucatu Medical School (FMB), São Paulo State University (UNESP), Botucatu, SP, Brazil. \\ ${ }^{5}$ Department of Structural and Functional Biology, Biosciences Institute (IB), University of Campinas (UNICAMP), Campinas, SP, Brazil. \\ ${ }^{6}$ Department of Animal Reproduction and Veterinary Radiology, School of Veterinary Medicine and Animal Husbandry, São Paulo State University (UNESP), \\ Botucatu, SP, Brazil.
}

\section{Keywords:}

Bone regeneration

Biomaterials

Fibrin sealant

Fibrin biopolymer

Biphasic calcium

phosphate

Mesenchymal stem cells

\section{ABSTRACT}

Background: Bone tissue repair remains a challenge in tissue engineering. Currently, new materials are being applied and often integrated with live cells and biological scaffolds. The fibrin biopolymer (FBP) proposed in this study has hemostatic, sealant, adhesive, scaffolding and drug-delivery properties. The regenerative potential of an association of FBP, biphasic calcium phosphate (BCP) and mesenchymal stem cells (MSCs) was evaluated in defects of rat femurs.

Methods: Adult male Wistar rats were submitted to a 5-mm defect in the femur. This was filled with the following materials and/or associations: BPC; FBP and BCP; FBP and MSCs; and BCP, FBP and MSCs. Bone defect without filling was defined as the control group. Thirty and sixty days after the procedure, animals were euthanatized and subjected to computed tomography, scanning electron microscopy and qualitative and quantitative histological analysis.

Results: It was shown that FBP is a suitable scaffold for bone defects due to the formation of a stable clot that facilitates the handling and optimizes the surgical procedures, allowing also cell adhesion and proliferation. The association between the materials was biocompatible. Progressive deposition of bone matrix was higher in the group treated with FBP and MSCs. Differentiation of mesenchymal stem cells into osteogenic lineage was not necessary to stimulate bone formation.

Conclusions: FBP proved to be an excellent scaffold candidate for bone repair therapies due to application ease and biocompatibility with synthetic calcium-based materials. The satisfactory results obtained by the association of FBP with MSCs may provide a more effective and less costly new approach for bone tissue engineering.

\footnotetext{
* Correspondence: claudia.v.cassaro@gmail.com http://dx.doi.org/10.1590/1678-9199-JVATITD-2019-0027 Received: May 04, 2019; Accepted: October 01, 2019; Published online: 04 November 2019
} 


\section{Background}

Regeneration of bone tissue starts immediately after its damage, and involves osteoinduction and osteoconduction, two phenomena that result in the reestablishment of the structure and function [1]. Throughout life, under normal conditions, this tissue is constantly renewed [2,3]. However, several factors may impair the repair process, such as extensive defects, trauma, infection, tumors, bone abnormalities and congenital malformations. The occurrence of non-unions require the use of grafts or implants that act as support and stimulate the process of tissue restoration. Thus, tissue engineering approaches aim to develop regenerative therapies for bone tissue in order to restore its shape and function by combining cells, signaling molecules and biocompatible materials, preferably associated with a bioactive scaffold [4].

Currently, autogenous bone grafts are still considered the gold standard in bone grafting due to their osteogenic properties [1]. However, their application presents drawbacks such as the limited amount of donor bone tissue and the need for a second surgery to remove the graft, causing an increase in recovery time. In this scenario, synthetic bone grafts offer an important alternative due to their unlimited availability [5]. Compounds containing calcium phosphates comprise the main class of biomaterials used in the replacement and in the regeneration of bone tissue. Their main characteristics include biocompatibility, bioactivity and absence of toxicity and immunogenicity. In addition, these materials are excellent osteoconductors and increase mechanical resistance at the defect site [6,7]. Among these materials are hydroxyapatite (HA), $\beta$-tricalcium phosphate (TCP) and a combination of the two known as biphasic calcium phosphates (BCP) [8]. This latter compound is widely used due to its additional advantage of controlling the level of degradation by adjusting the proportion between the two components [7].

The association between calcium phosphate materials and mesenchymal stem cells presents good osteogenic potential, since these stem cells have an appropriate surface for cellular adhesion and activity, thus acting as a stimulus for the differentiation in osteoblasts [9-13]. Moreover, the unique ability of mesenchymal cells to promote bone healing, combined with their ease of isolation, provides a more appropriate therapy for patients who suffer from limitations in the regeneration of this tissue [14,15]. However, for satisfactory cell action, adequate anchoring at the application site is imperative, and may be provided by a biological scaffold. Three-dimensional scaffolds provide a suitable environment for tissue regeneration, acting as a framework for bone formation and are easily implanted with cells, biomaterials or growth factors, thus providing structural and environmental stability for cell and tissue regeneration [16-19].

Fibrin sealants are natural biopolymers endowed with adhesive, sealant, and hemostatic properties, and are suitable for cell adhesion and tissue stability. They are widely used as scaffolds and in drug delivery systems, enabling the precise application of biomaterials, cells, enzymes or growth factors [20-22]. Traditional commercial fibrin sealants have been produced from thrombin obtained from human or bovine blood, and human fibrinogen [22,23]. This biomaterial, under exceptional conditions, can transmit bloodborne diseases $[23,24]$. Therefore, researchers from the Center for the Study of Venoms and Venomous Animals (CEVAP) at São Paulo State University (UNESP), Brazil, proposed the production of a new fibrin biopolymer (FBP), previously identified as heterologous fibrin sealant, which does not use human blood derived products. Thus, a thrombin-like serine protease enzyme isolated from Crotalus durissus terrificus snake venom, and a cryoprecipitate rich in fibrinogen extracted from Bubalus bubalis were employed [25]. This product was patented, tested through several animal experiments and approved by the Brazilian Health Regulatory Agency (ANVISA) for phase I/II clinical trials in the treatment of patients with chronic venous ulcers, in which the product was proven safe [25-45].

It was shown that the fibrin biopolymer produced by CEVAP has an excellent interaction with the mesenchymal stem cells derived from the bone marrow of rats [30]. It forms a three-dimensional structure that enables cell adhesion, differentiation and proliferation, properties also observed in commercial polymers $[46,47]$. In addition, satisfactory results were obtained by associating FBP with synthetic hydroxyapatite in the treatment of cranial defects in rats [43]. Recently, an association between FBP and mesenchymal stem cells in femoral defects of osteoporotic rats was also validated [45].

Therefore, the present study aimed to evaluate for the first time the repair potential of calcium phosphate biomaterial applied together with FBP associated or not with mesenchymal stem cells in rats submitted to a femoral bone defect.

\section{Methods}

\section{Animals}

Eighty male Wistar rats (Rattus norvegicus) weighing an average of $350 \pm 20 \mathrm{~g}$ were randomly divided into five experimental groups, while ten rats aged 21 days were submitted to bone marrow harvest to achieve mesenchymal stem cell expansion. The rats were provided by the animal house of the Laboratory of Experimental Medicine, UNESP, Botucatu. All animals were kept at $21 \pm 2{ }^{\circ} \mathrm{C}$ under a 12-hour light/dark cycle, with access to food and water ad libitum. The present study was approved by the Animal Ethics Committee of Botucatu Medical School, São Paulo State University (UNESP - protocol number 1164/2016).

\section{Fibrin Biopolymer}

The fibrin biopolymer (FBP) (Fig. 1A) was supplied by CEVAP. The components and formula of the product are covered by patents (registry numbers: BR1020140114327 and BR1020140114360). The components were mixed upon use as follows: $10 \mu \mathrm{L}$ of fraction 1 (gyroxin), $25 \mu \mathrm{L}$ of fraction 2 (fibrinogen cryoprecipitate) and $15 \mu \mathrm{L}$ of fraction 3 (diluent); resulting in a final volume of $50 \mu \mathrm{L}$ of sealant and maintaining the standard concentration. 


\section{Biphasic Calcium Phosphate Biomaterial}

The biphasic calcium phosphate (BCP) (Graftys ${ }^{\circ}$ BCP, Graftys Sarls, France, Anvisa n. 80517190002) (Fig. 1B) was kindly supplied by LAS Brasil importer. The synthetic material was presented in granules varying between 0.5 and $1 \mathrm{~mm}$ and consisted of $60 \%$ of hydroxyapatite and $40 \%$ of $\beta$-tricalcium phosphate. Its porosity varied between $\leq 10 \mu \mathrm{m}$ and $100 \mu \mathrm{m}$ [48]. Fifteen milligrams of previously aliquoted and stored material was implanted at the site of interest.

\section{Mesenchymal Stem Cells Isolation and Expansion}

In order to harvest the cells from bone marrow, rats were euthanized by isoflurane overdose at minimum alveolar concentration (MAC > 5\%) and, after the unconsciousness of the animals was confirmed, cervical dislocation. Bone marrow cells were obtained by centrifugation of the femurs and tibias, which were vertically positioned in conical tubes containing $1000 \mu \mathrm{L}$ of Dulbecco's Modified Eagle Medium (DMEM ${ }^{\circledR}$, GibcoInvitrogen, USA) high glucose, and centrifuged at 2,500 rpm for four minutes. The bones were then discarded and the precipitate was resuspended.

The obtained solution was transferred to $25 \mathrm{~cm}^{2}$ culture flasks containing $4 \mathrm{~mL}$ of $\mathrm{DMEM}^{\circledR}$ (supplemented with $20 \%$ fetal bovine serum, $100 \mu \mathrm{g} / \mathrm{mL}$ penicillin/streptomycin and $3 \mu \mathrm{g} / \mathrm{mL}$ amphotericin B), comprising a total volume of $5 \mathrm{~mL}$. The flasks were kept in an incubator with a $5 \% \mathrm{CO}_{2}$ atmosphere at $37.5^{\circ} \mathrm{C}$. The culture medium was replaced every 3 to 5 days, depending on the growth of cells and adherence on the bottle surface, both monitored by light microscopy.

When cells reached about $90 \%$ confluence, the cell passage was performed. For this process, the culture medium in the flask was discarded; $2 \mathrm{~mL}$ of phosphate-buffered saline (PBS) was added for washing and discarded thereafter. After washing, $2 \mathrm{~mL}$ of trypsin was added and the flask was maintained in the incubator for five minutes. With the cells in suspension, $2 \mathrm{~mL}$ of supplemented $\mathrm{DMEM}^{\bullet}$ was added. The solution was then transferred to $15-\mathrm{mL}$ conical tubes and centrifuged at 1700 rpm for ten minutes. After centrifugation, the supernatant was discarded and the pellet containing the cells was resuspended in $1000 \mu \mathrm{L}$ of $\mathrm{DMEM}^{\bullet}$. The solution was then transferred to flasks of the appropriate size.

\section{Characterization}

Cultivated mesenchymal stem cells (MSCs) on the fourth passage were characterized by flow cytometry (BD FACSCalibur ${ }^{\mathrm{rw}}$, BD Biosciences)FACS Calibur'; BD Pharmingen) using the positive surface markers $\mathrm{CD} 90, \mathrm{CD} 44$ and ICAM-1, and negative expression markers CD45, CD11b, MHC class I and RT1-aw2 [49]. Specifications of each marker are presented in Additional file 1. The preparation consisted of an adjustment in cell volume to 2

$\times 10^{5}$ cells per tube/marker. Antibodies were added according to specific dilution also described in Additional file 1. The samples were then incubated at room temperature for one hour and washed with PBS [45].

\section{Association of FBP with Mesenchymal Stem Cells and Calcium Phosphate}

At the bone defect site and depending on the group, $50 \mu \mathrm{L}$ of FBP, $15 \mathrm{mg}$ of biphasic calcium phosphate, and $10 \mu \mathrm{L}$ of complete culture medium containing an average of $3 \times 10^{5} \mathrm{cells}$ previously characterized were added. In the group in which only the biphasic calcium phosphate (G2) was implanted, the granules were placed directly at the lesion/implant receptor site, adding and compacting the granules with the help of a spatula. For the association of BCP and FBP (G3), the fractions 2 and 3 of the latter were homogenized on a cell culture plate, the calcium phosphate was added and, finally, fraction 1 was added. The clot formed was then transferred to the defect site.

After counting the mesenchymal stem cells, and associating them with FBP only (G4) or FBP and with BCP (G5), a 2-mL volume was transferred to microtubes and centrifuged. Next, the cells were resuspended in 2-mL microtubes, comprising a complete medium volume of $10 \mu \mathrm{L}$, and then added to a microtube containing the calcium-based biomaterial and the FBP fractions as previously described. The formed clot was then transferred to the lesion site. In the control group, no material was received.

\section{In Vivo Experimental Procedures}

\section{Experimental Design}

A 5-mm bone defect was performed on the right femur of each rat, described as follows. Animals were divided into five experimental groups of eight individuals each, namely:

- Group 1 (G1): bone defect without material filling (control group).

- Group 2 (G2): bone defect filled with BCP.

- Group 3 (G3): bone defect filled with FBP + BCP.

- Group 4 (G4): bone defect filled with FBP + MSCs.

- Group 5 (G5): bone defect filled with FBP + BCP + MSC.

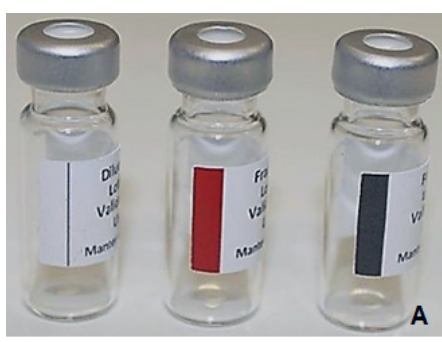

Figure 1. (A) Fibrin biopolymer vials [26]. (B) Presentation of the biphasic calcium phosphate: aspect of the granules.

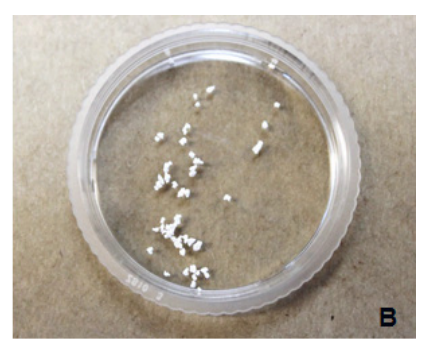




\section{Femur-Defect Surgical Procedure}

Animals were anesthetized with isoflurane at MAC of 3\% for induction and $1.5 \%$ for maintenance, without need for mechanical ventilation. After confirmation of anesthetic induction, the animals were placed in lateral decubitus position and trichotomy was performed on the anterior region of the right thigh. A medial longitudinal incision was made on the skin of the anterior distal third of the region. The skin was laterally removed, and then the femoral quadriceps muscle was separated exposing the periosteum, which was sectioned transversely and disjointed from the bone surface.

After exposure of the bone tissue, a bone defect of $5 \mathrm{~mm}$ diameter and $2 \mathrm{~mm}$ width was induced using a drill bit coupled to a dental micromotor (Beltec ${ }^{\oplus}$ model LB100; Brazil) at about $3000 \mathrm{rpm}$, thus promoting a bone defect in the proximal third of the right femur diaphysis (Fig. 2). Throughout the defect induction procedure, the lesion site was irrigated continuously with physiological solution in order to avoid overheating in the region. According to the group, the mixture of components was added to the promoted bone defect. After stabilizing the graft, suturing was performed. In the postoperative period, the animals received food and water ad libitum and were not immobilized at any time. The rats received postoperative analgesia consisting of tramadol hydrochloride at $5 \mathrm{mg} / \mathrm{kg}$, ketoprofen at $5 \mathrm{mg} /$ $\mathrm{kg}$ (Ketofen ${ }^{\circ} 10 \%$ ) and enrofloxacin hydrochloride at $8 \mathrm{mg} /$ $\mathrm{kg}$ (Chemitril $\left.{ }^{\circ} 2.5 \%\right)$ subcutaneously at 12 -hour intervals for three days [51].

\section{Euthanasia}

Animals were euthanized by isoflurane overdose (MAC > 5\%) and, after the unconsciousness of the animals was confirmed, cervical dislocation. The procedure occurred in two periods for observation and analysis of samples: at 30 and 60 days after surgery, four animals from each group were euthanized. In these two periods, before euthanasia, the region of interest was scanned by computed tomography. The collected bones were then forwarded for histological and for scanning electron microscopy analysis. The macroscopic aspect of the femurs and surrounding areas at the moment of euthanasia was also considered.

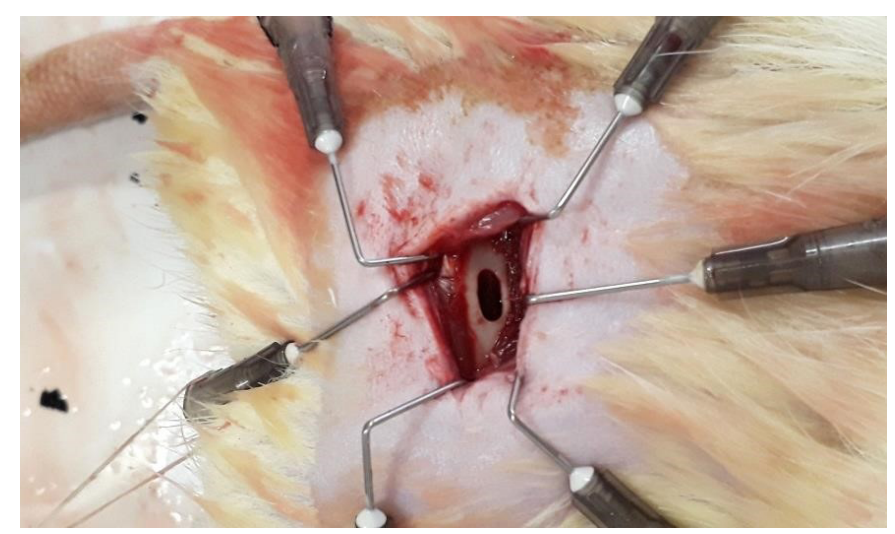

Figure 2. Femoral 5-mm bone defect site.

\section{Computed Tomography Analysis}

At 30 and 60 days after the surgical procedure, the animals were submitted to computed tomography (CT) scan in order to evaluate the repair process at the lesion site. The procedure was carried out by a helical single-channel tomograph (Shimadzu SCT7800 TC, Japan), whose additional specifications are displayed in Additional file 2. For the scan, animals were previously anesthetized with ketamine and xylazine hydrochloride at the dose of $0.10 \mathrm{~mL} / 100$ grams of body mass and positioned in dorsal decubitus. The images obtained were studied in the cross-sectional, longitudinal and coronal sections, whereas the tomographic-graphical appearance of the implants was evaluated considering adjacent opacification, Hounsfield Unit values, bone proliferation, consolidation and remodeling processes in the region of interest [52].

\section{Scanning Electron Microscopy (SEM) Analysis}

After collection, the femurs were initially fixed in Karnovsky's solution for 36 hours. After fixation, samples were washed in phosphate buffer and immersed in $0.5 \%$ osmium tetroxide solution for 60 minutes and then dried to the critical point, positioned over stubs and coated with gold (sputtering process). The samples were analyzed using a Jeol ${ }^{\bullet}$ JSM 5800LV (USA) microscope at $10 \mathrm{kV}$.

\section{Histological Analysis}

The femurs were collected and fixed in $10 \%$ formaldehyde solution for 24 hours. Subsequently, the material was subjected to decalcification in $30 \%$ formic acid solution for 15 days. After decalcification, the bones were reduced to the region of interest, fixed in $70 \%$ alcohol for 12 hours, dehydrated in an increasing series of ethanol, diaphanized in xylol and, finally, embedded in paraffin. Semi-serial longitudinal $5-\mu \mathrm{m}$ sections of the bone tissue were obtained and stained with hematoxylin and eosin (HE). The slides obtained were visualized and photographed (Leica DM500 ${ }^{\circ}$ microscope, Leica DMC2900 ${ }^{\circ}$ camera; Germany) with aid of the equipment described in Additional file 3 at magnifications of $4 \mathrm{x}, 10 \mathrm{x}$ and $20 \mathrm{x}$, to evaluate morphological characteristics. Stereological analysis was performed based on images obtained by $10 x$ magnification (Zeiss Stemi $2000^{\circ}$ magnifier, Germany; Dino Eye AM7025X' Taiwan) according to the methodology described by Weibel et al. [53] in order to quantify formed bone, biomaterial, bone marrow and cellularized connective tissue on lesion area.

\section{Statistical Analysis}

Based on the results of the stereological analysis, the groups were compared by ANOVA, followed by Tukey's test for multiple comparisons. Differences were considered statistically significant if $\mathrm{p}<0.05$. The data analysis was performed using the software SPSS version 21.0. 


\section{Results}

\section{Mesenchymal Stem Cell Characterization}

The applied mesenchymal stem cells presented the expressions represented in histograms shown in Figure 3 and were positive for the markers CD90 (98.29\%), CD44 (63.21\%) and ICAM1 (99.3\%), and negative for CD45 (6.57\%), CD11b (4.35\%), RT1aw2 (9.4\%) and MHC Class II (3.54\%), in agreement with the literature $[49,54]$.

\section{Surgical Procedure and Euthanasia}

At the time of surgery, the group presenting the easiest application of materials was FBP, given that the clot formed by FBP contained biphasic calcium phosphate while its mesenchymal stem cells (Fig. 4) were much easier to handle, mold and accommodate at the injury site (Fig. 5).

After the surgery, the incision site showed no signs of inflammation and animals presented normal locomotion. At the time of euthanasia, no inflammatory infiltrates or rejection at the graft site was observed.

\section{CT Analysis}

Through the images obtained by tomography (Fig. 6), a lesion site was visible in all groups and periods. The quantitative parameter evaluated was the HU value (Hounsfield units) (Fig. 7), a measure related to the density of the tissue in formation, which in normal cortical bone tissue has a value of $1000 \mathrm{HU}$ or more [52]. At 30 days, the mean value per group was less than 1000 only in the control group. At 60 days, the $\mathrm{HU}$ value was higher than 1000 in all groups, but the control still presented the lowest value among all groups.

According to the qualitative parameters considered, proliferation - which indicates bone activity at the lesion site - suggested that the total consolidation had not yet occurred at day 60 . In addition, remodeling in the region was also active at 60 days, but the control group showed cortical misalignment and separation between the edges of the lesion (Table 1). Opacification, which indicates the similarity of the radiopacity area of the lesion within adjacent intact tissue, was greater in the groups in which biphasic calcium phosphate was applied. Detailed information about the parameters evaluated is contained in Additional file 4.

\section{Macroscopic Aspect and SEM Analysis}

Figures 8 and 9 show the general aspect of the lesion region at 30 and 60 days after the surgical procedure, at the moment in which material was collected after euthanasia and subjected to scanning electron microscopy (SEM). Macroscopically and at 30 days, the edges of the lesion were distinguishable in all experimental groups, with a significant approximation of the edges of the lesion in Group 4. Through microscopic images, groups 1 and 4 (both without biphasic calcium phosphate material) showed uniform coverage at the lesion site, while the groups treated with calcium phosphate presented the characteristic morphology of the granules.

At 60 days, the approximated edges of the lesion were visible in all the groups, with integration of the lesion edges into the applied association, but without apparent resorption in the central region in the groups that received the biomaterial. The images obtained through the scan corroborate the approximation of the lesion margins and did not enable visualization of the lesions. The control group and the group receiving association of fibrin biopolymer and cells (Group 4) presented total superficial coverage in the lesion area. Yet again, calcium phosphate remained without great resorption in the central region of the lesion.

\section{Histological Analysis}

Figures 10 and 11 present the images of the histological sections stained with hematoxylin and eosin from the defect region 30 and 60 days after implantation. Progressive deposition of bone matrix was detectable in all groups. Groups 2, 3 and 5 showed integration of the calcium phosphate biomaterial into the adjacent newly formed matrix, with a large presence of resorption lacunae, which were less numerous in Group 2. In Group 4, the bone formation was very copious, linear and organized, with few bone marrow infiltrates. In groups 2 and 5 and at 30 days, a greater presence of highly cellularized connective tissue was observed.

At 60 days, the depositions of bone matrix were similar in groups 2, 3, and 5, and more evident in Group 4, which received the association of fibrin biopolymer and mesenchymal stem cells. The bone formation in the treated groups, quantified by stereological analysis (Figs.12 and 13; Additional file 3), can be represented by: $\mathrm{FBP}+\mathrm{MSC}>\mathrm{FBP}+\mathrm{BCP}+\mathrm{MSC}>\mathrm{FBP}+\mathrm{BCP}$ $>$ BCP. Statistical analysis showed significantly higher bone formation in Group 4 (Table 2; Additional file 4).

Table 1. Qualitative parameters for bone growth and consolidation by CT scan.

\begin{tabular}{|c|c|c|c|c|c|c|c|c|c|c|}
\hline & \multicolumn{2}{|c|}{ Group 1} & \multicolumn{2}{|c|}{ Group 2} & \multicolumn{2}{|c|}{ Group 3} & \multicolumn{2}{|c|}{ Group 4} & \multicolumn{2}{|c|}{ Group 5} \\
\hline & 30 days & 60 days & 30 days & 60 days & 30 days & 60 days & 30 days & 60 days & 30 days & 60 days \\
\hline Proliferation & - & -+ & + & + & + & + & + & ++ & + & + \\
\hline Opacification & -+ & -+ & ++ & ++ & ++ & ++ & + & + & ++ & ++ \\
\hline
\end{tabular}

-: absent; -+: minor significance; +: limited significance; ++: significant. 
Cassaro et al. J Venom Anim Toxins incl Trap Dis, 2019, 25:e20190027

Page 6 of 17
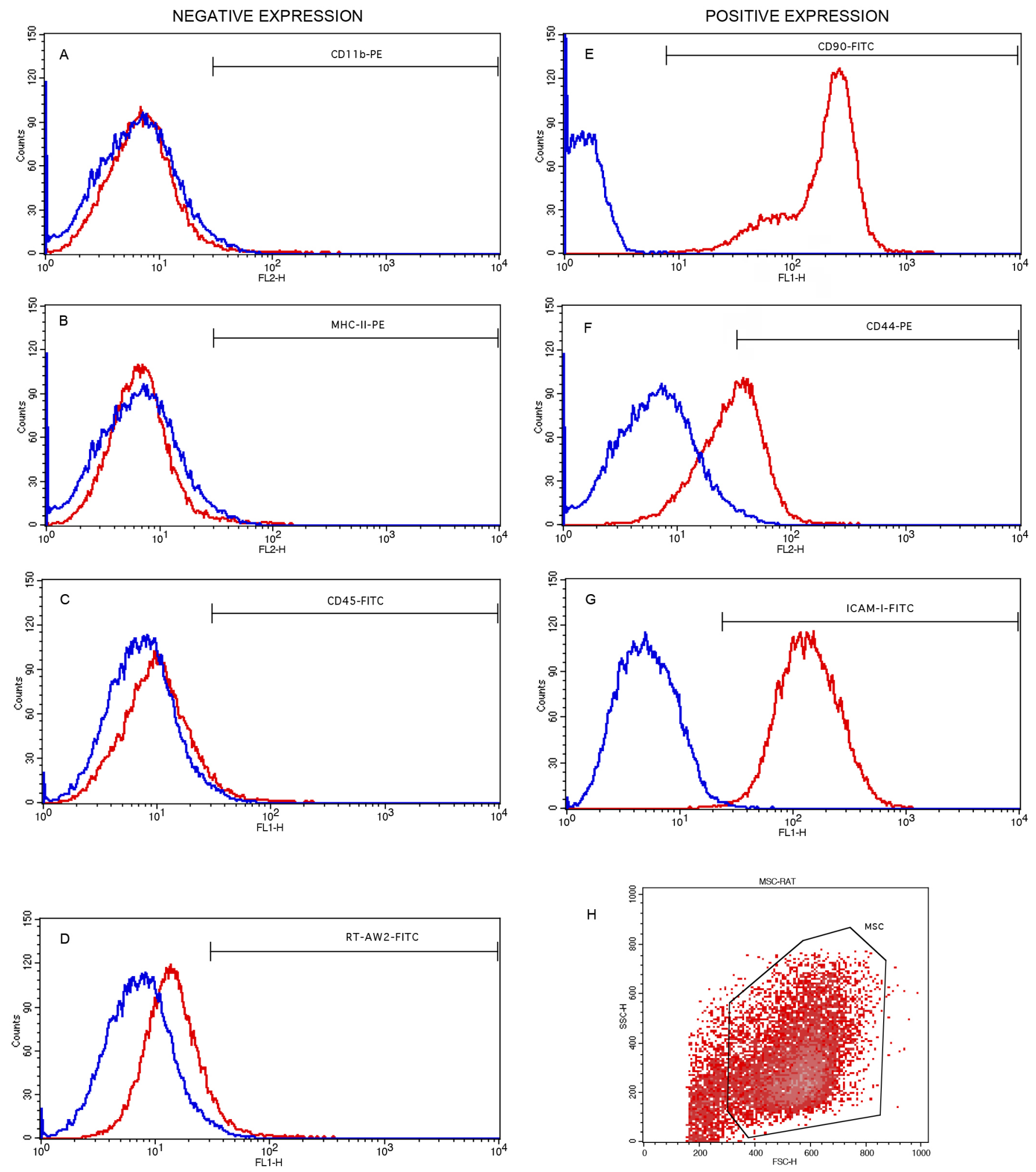

Figure 3. Flow cytometry analysis of mesenchymal stem cells characterized by surface markers. Blue line: negative markers; red line: positive markers. (A) CD11B, (B) MHC class II, (C) CD45, (D) RT1-Aw2, (E) CD 90, (F) CD44, (G) ICAM1, and (H) gate of analyzed cell population. 
In the control group, the bone matrix still presented a disorganized pattern and was permeated by bone marrow. Although there was bone formation in the control group, it did not evolve significantly from 30 to 60 days.

Despite the high level of bone formation around the calcium phosphate granules, no noteworthy cell proliferation was observed inside the biomaterial granules until 60 days after implantation (Fig. 14). The reabsorption of these materials was evidenced by the presence of resorption gaps and the difference in their appearance at 30 and 60 days (Fig. 15). In turn, the FBP was not visible 30 days after implantation. In the groups where phosphate and polymer were applied, with or without addition of stem cells, there was an abundant presence of highly cellularized connective tissue at 30 days.

\section{Discussion}

The present study has evaluated, for the first time, the application and repair potential of the FBP as a biological scaffold for a biphasic calcium phosphate biomaterial associated with mesenchymal stem cells in a bone defect induced in rat femurs.

The addition of the calcium phosphate material and mesenchymal stem cells to the FBP scaffold during the surgery improved the handling and application of the association due to the formation of a moldable composite, thus reducing the time of the surgical procedure [55-58]. This was due to the malleability of the dense fibrin network formed during the stabilization of the clot [30] Previous studies applying the FBP also reported as advantages a shortening of the procedure time $[38,39]$, easier handling and greater flexibility of the scaffold $[38,37]$. Gonçalves et al. [42] highlighted the stability at the receptor site provided by this scaffold. During the collection of femurs, no inflammatory infiltrates or rejection at the graft site and surrounding muscular tissue was observed, demonstrating the biocompatibility of the materials and thereby corroborating the literature $[41,43,59,60]$.

The tomographic images indicated that total consolidation had not yet occurred after 60 days, requiring a longer period to determine the outcome of the repair process. It was verified that opacification was greater in the groups in which the biphasic calcium phosphate was applied, which was expected due to its similarity with the bone $[61,62]$. However, using bone density as the only parameter is not indicated as a single approach to determine the injury repair progression when calcium is applied. This approach may indicate a false overview of the recovery process.

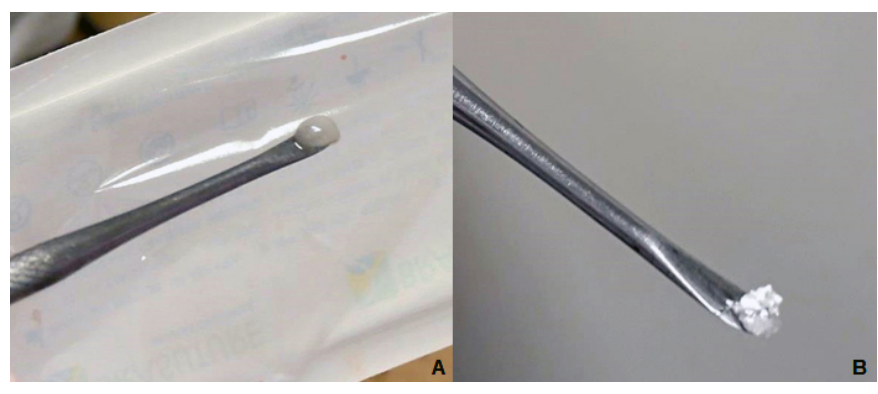

Figure 4. Stable clot formed by fibrin biopolymer containing (A) mesenchymal stem cells and (B) biphasic calcium phosphate.

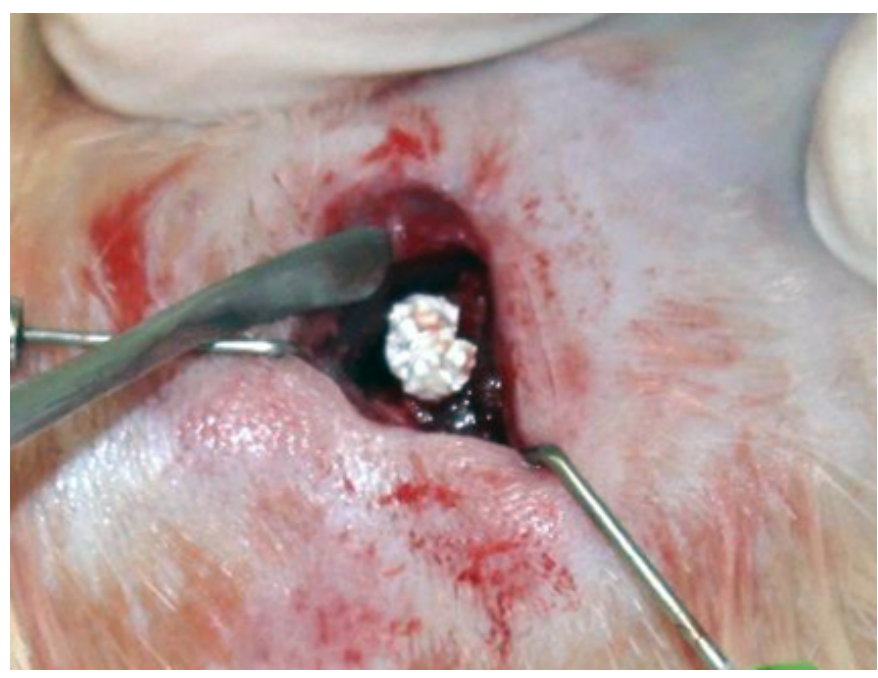

Figure 5. Implantation of the composite at the bone defect site.

Table 2. Statistical comparison among groups by ANOVA test. Data presented by mean and standard deviation.

\begin{tabular}{|c|c|c|c|c|c|c|}
\hline Variable & G1 (control) & $\begin{array}{c}\text { G2 } \\
\text { (BCP) }\end{array}$ & $\begin{array}{c}\text { G3 } \\
(\text { FBP + BCP) }\end{array}$ & $\begin{array}{c}\text { G4 } \\
(\text { FBP + MSC) }\end{array}$ & $\begin{array}{c}\text { G5 } \\
(\mathrm{FBP}+\mathrm{BCP}+ \\
\mathrm{MSC})\end{array}$ & $p$ value \\
\hline FB30* & $56.5 \pm 5.6$ & $38.7 \pm 4.6$ & $28.4 \pm 5.1$ & $65.3 \pm 4.1$ & $39.7 \pm 15.3$ & $<0.001$ \\
\hline BW30 & $43.4 \pm 5.6$ & $20.2 \pm 10.7$ & $7.8 \pm 3.6$ & $34.6 \pm 4.1$ & $2.3 \pm 2.8$ & $<0.001$ \\
\hline FB60 & $57.6 \pm 11.3$ & $45.4 \pm 12.2$ & $48.4 \pm 5.7$ & $75 \pm 2.7$ & $58.3 \pm 7.8$ & 0.002 \\
\hline BW60 & $42.3 \pm 11.3$ & $12 \pm 5.8$ & $7.7 \pm 1.9$ & $25 \pm 2.7$ & $1.6 \pm 1.9$ & $<0.001$ \\
\hline DiffB & $1.2 \pm 6.7$ & $6.6 \pm 14.8$ & $19.9 \pm 10.2$ & $9.6 \pm 5$ & $18.6 \pm 14.3$ & 0.128 \\
\hline DifBW & $-1.1 \pm 6.7$ & $8.2 \pm 13.3$ & $-0.075 \pm 5.3$ & $-9.6 \pm 5$ & $-0.6 \pm 4.3$ & 0.271 \\
\hline
\end{tabular}

*FB30: G1 > G3; G4 > G2, G3, G5 (Tukey; p < 0,05)

FB30: newly formed bone 30 days after surgical procedure; FB60: newly formed bone 60 days after surgical procedure; BW30: bone marrow presence 30 days after surgical procedure; BW60: bone marrow presence 60 days after surgical procedure; Dif: diference between 30 and 60 days. 

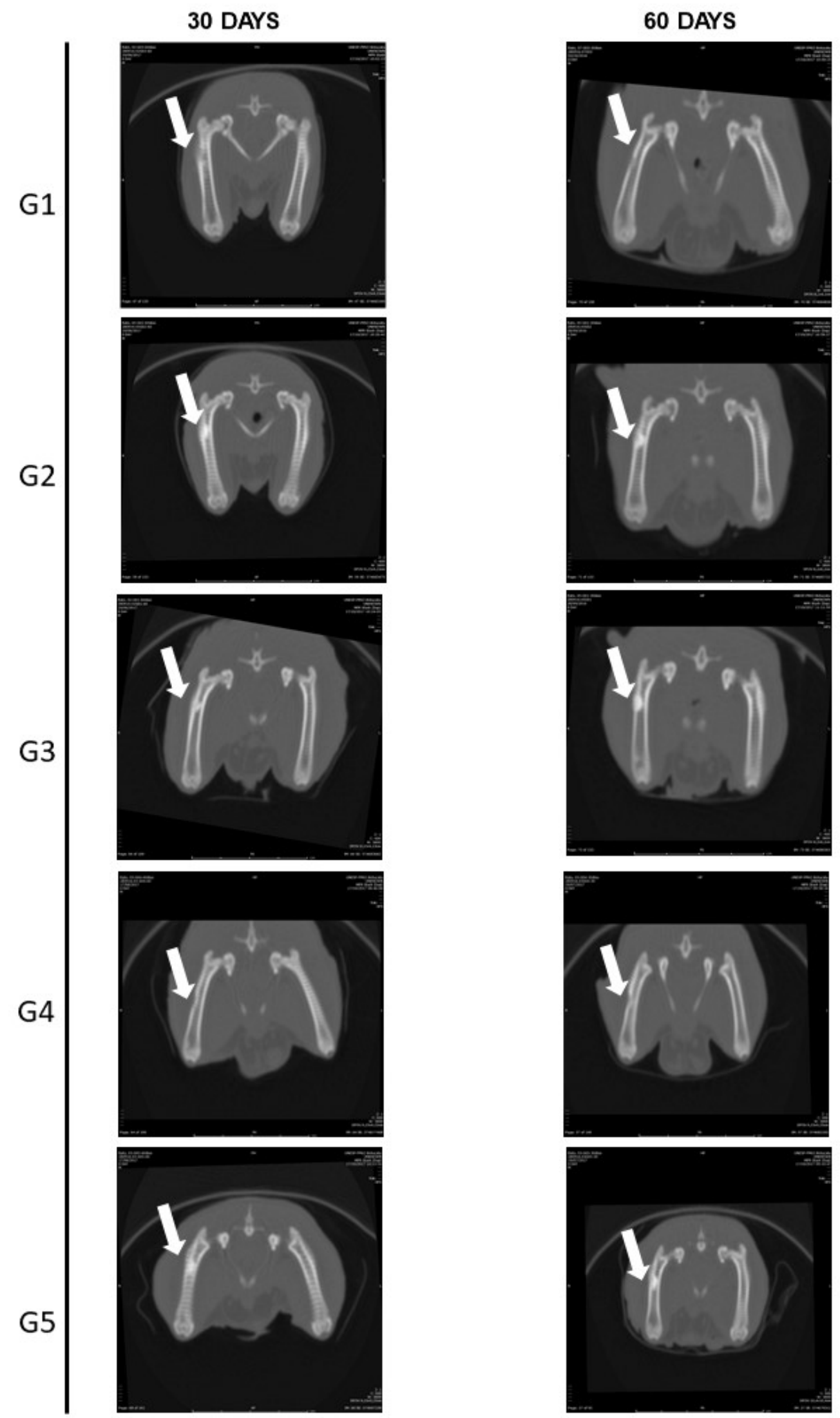

Figure 6. Representative images on coronal plane of the right femur of rats submitted to bone defect (white arrows) at 30 and 60 days after surgical procedure by CT scan. 


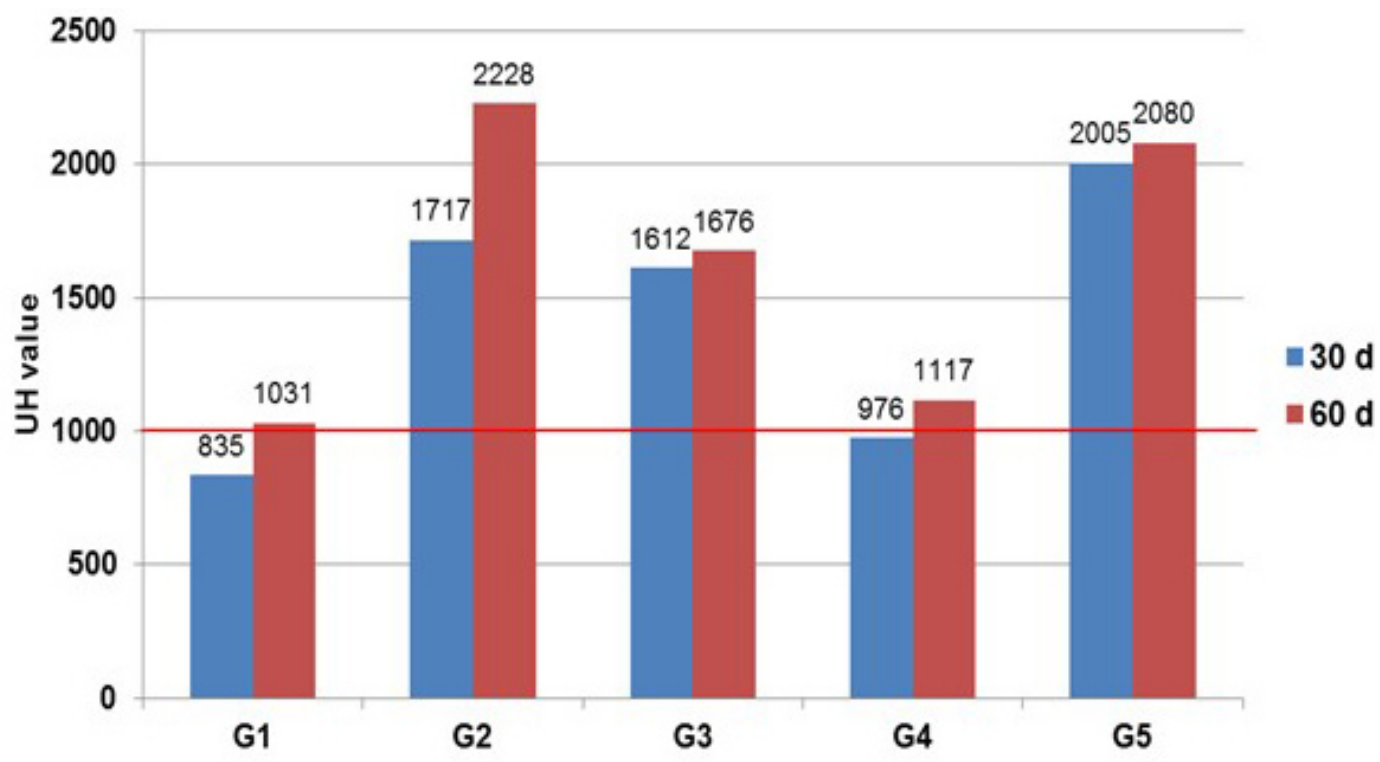

Figure 7. Mean Hounsfield unit $(\mathrm{HU})$ value at the defect site of all groups 30 and 60 days after surgical procedure. Observation by $\mathrm{CT}$ scan. Red line indicates minimum value expected for regular cortical bone.

The HU value is directly related to the density of the tissue in formation, where the higher bone density found in the treated groups may indicate tissue formation that is more compact and, therefore, more resistant $[63,64]$. This parameter in isolation cannot reveal whether the density was due to the presence of newly formed bone or of implanted material. In order to clarify these questions, a qualitative analysis of the defect site was required.

It is known from the literature that, after bone injury, the process of resorption is initiated, followed by proliferation and consolidation, which may or may not result in adequate remodeling $[52,65]$. The qualitative parameters observed in CT images indicated poor cell proliferation and remodeling in the control group, indicating that the applied associations acted as a guide for the repair process, and the application of the tested combinations improved the level of cellular migration to the lesion site [66].

The approximation of the lesion borders viewed macroscopically and by SEM from 30 to 60 days follows the expected remodeling pattern $[67,43]$. The characteristic granular morphology of the material was also observable $[67,68]$. In additional to these observations, the histological images provided a morphological overview of the tissue formation. The progressive deposition indicates the osteoconductive potential of the materials applied $[59,69,70,71]$. Characteristics such as regeneration from the edges of the lesion, bone formation around the applied materials and more numerous resorption gaps at 60 days are in accord with the literature $[43,56,62,71-74]$. The deposition of bone matrix was higher in Group 4, which received the association of FBP together with MSCs. Besides the apparent similarity in coverage between Group 4 and control group shown by SEM images, histological analysis revealed that the control group presented a less organized tissue and more infiltrated bone marrow in formed bone. In agreement with the SEM analysis, no resorption was detected inside the calcium phosphate granules in histological sections, but resorption lacunae indicate that this was occurring, but at a slow rate.

Due to the characteristic deposition of the bone tissue in formation around the calcium phosphate materials when they were implanted [75], and the linear pattern of formation in their absence, the stereological quantification [53] enabled more precise measurement of the proportion of bone formed and other constituents in the sections obtained from the defect region. The quantitative analysis corroborates that Group 4 presented greater deposition of bone matrix, in agreement with traditional sealant studies [30,45, 47,76-79].

Although the association between FBP, cells and calcium phosphate presented less bone formation than FBP and cells, the former group showed less bone-marrow infiltration in the tissue in formation, indicating the stability provided by the association between fibrin-based scaffolds and other materials [80,81]. In addition, this group presented more bone formation than the association containing only the FBP and calcium phosphate, once again showing the osteogenic improvement provided by MSC transplantation [12,30,77].

In the control group the bone matrix still presented a disorganized pattern and was permeated by bone marrow, indicating a lower bone density and lower resistance. In addition, there was no apparent evolution of the deposition in the bone matrix from 30 to 60 days; this finding highlights the importance of the application of bioactive materials to stimulate osteoprogenitor cell proliferation [82]. 


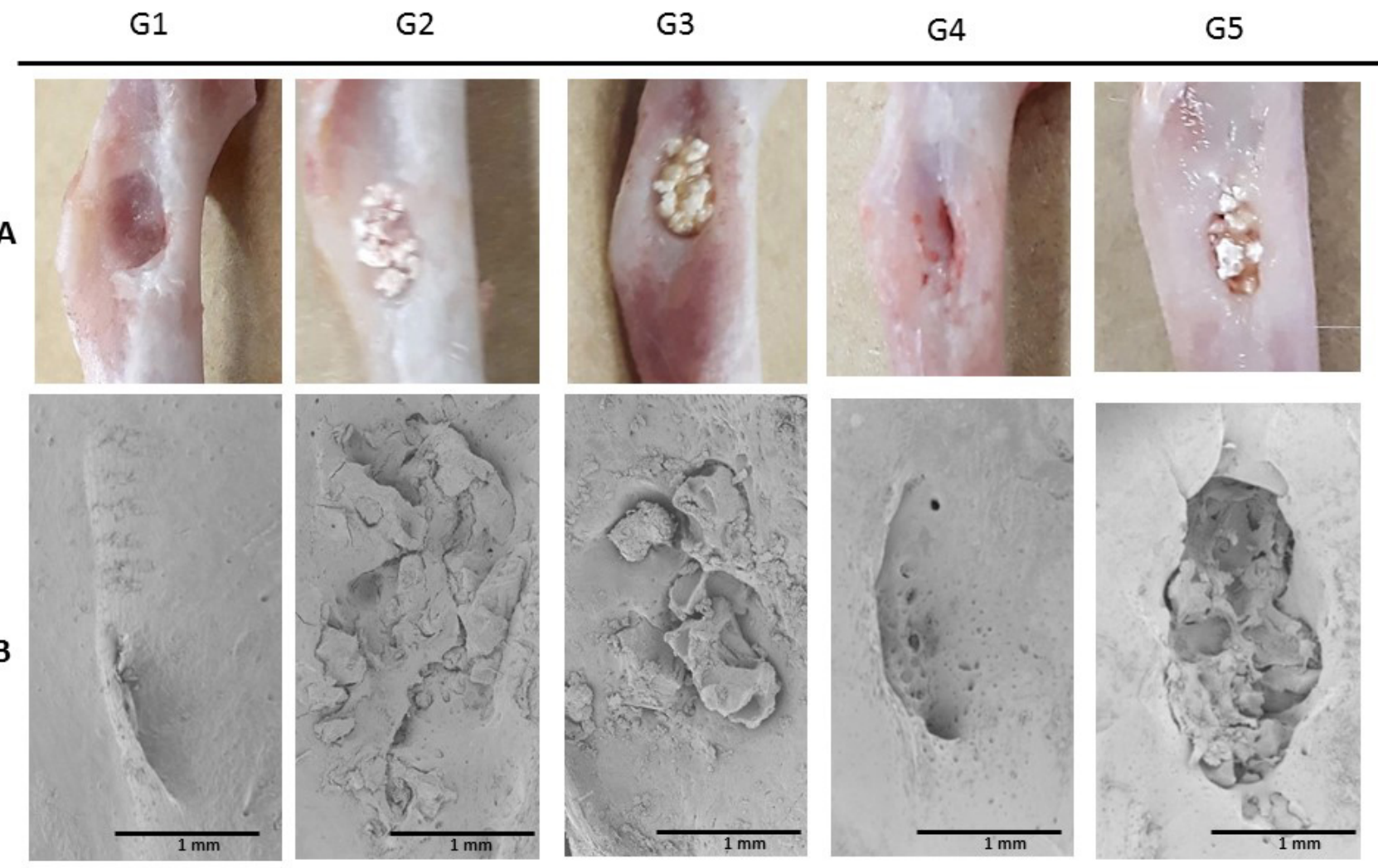

Figure 8. Representative images of the region of interest: (A) macroscopic and (B) by scanning electron microscopy view, 30 days after surgical procedure.

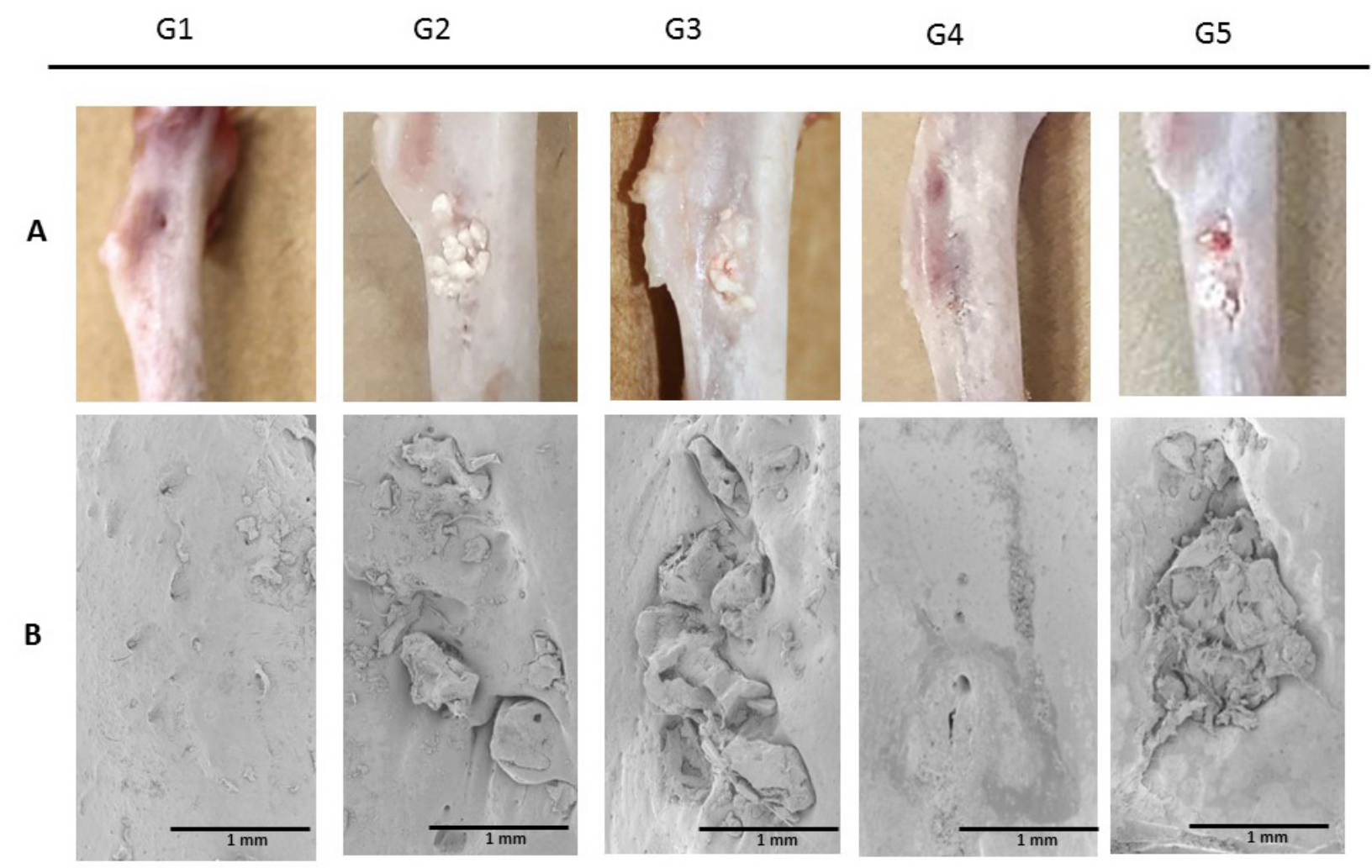

Figure 9. Representative images of the region of interest: (A) macroscopic and (B) by scanning electron microscopy view, 60 days after surgical procedure. 


\section{G1}
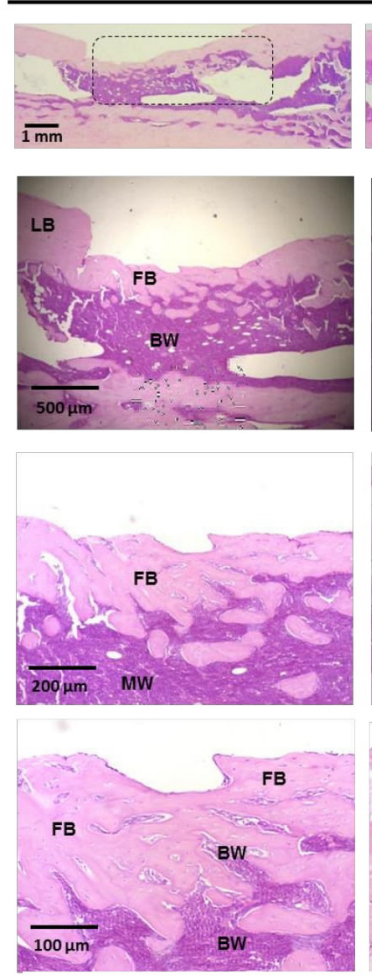

$\mathrm{G} 2$
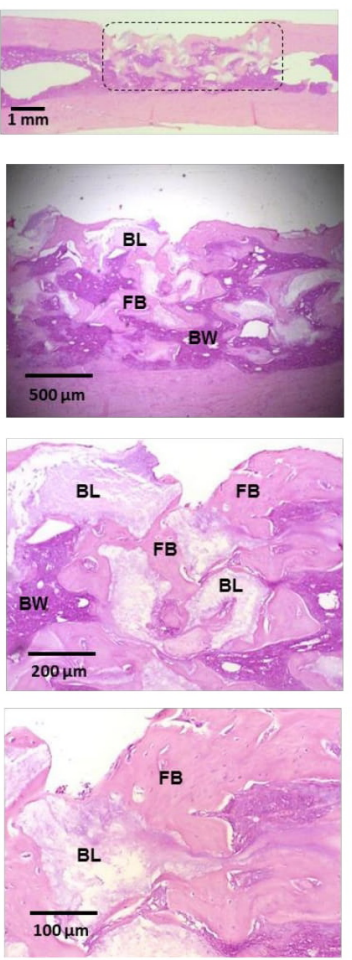

G3

G4

G5
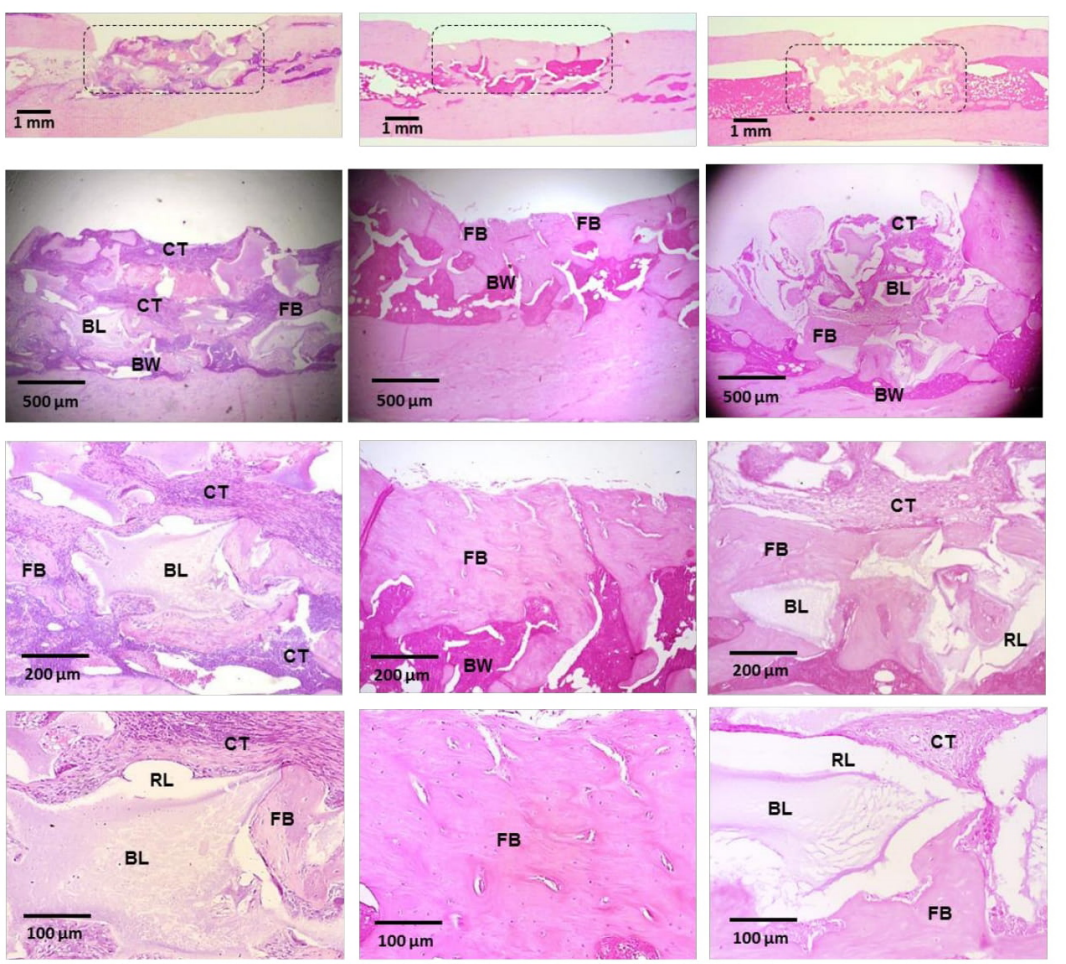

Figure 10. Representative images of histological sections stained with hematoxylin and eosin from the region of interest at 30 days after surgical procedure. LB: adjacent lamellar bone; FB: newly formed bone; BL: calcium phosphate biomaterial; RL: resorption lacunae; BW: bone marrow; CT: cellularized connective tissue.

\section{G1}
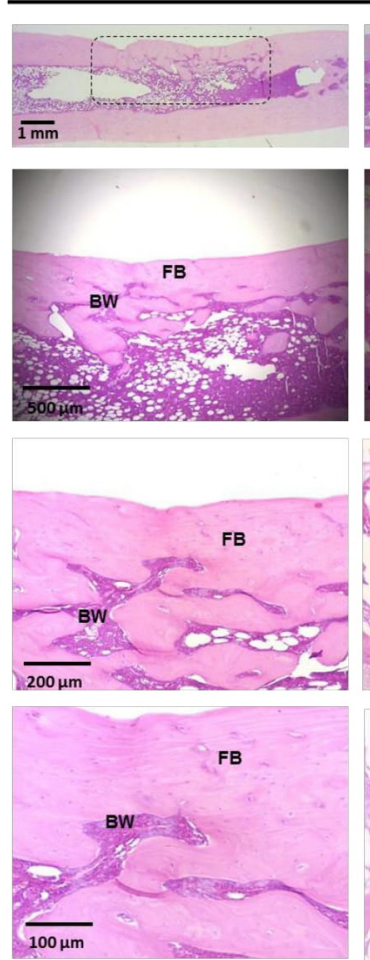

\section{G2}
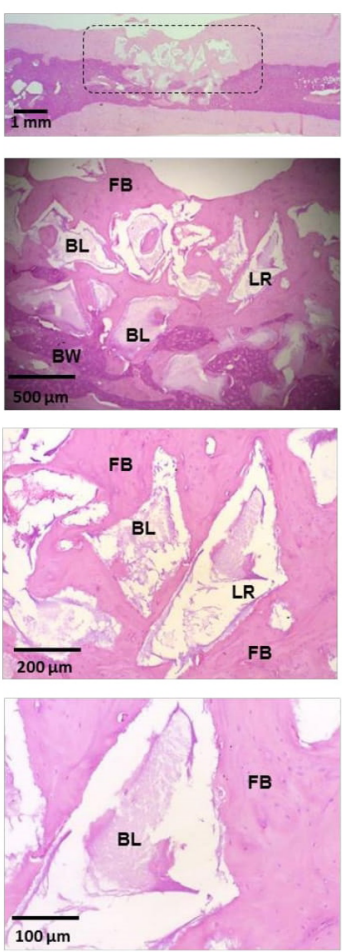

G3

G4

G5
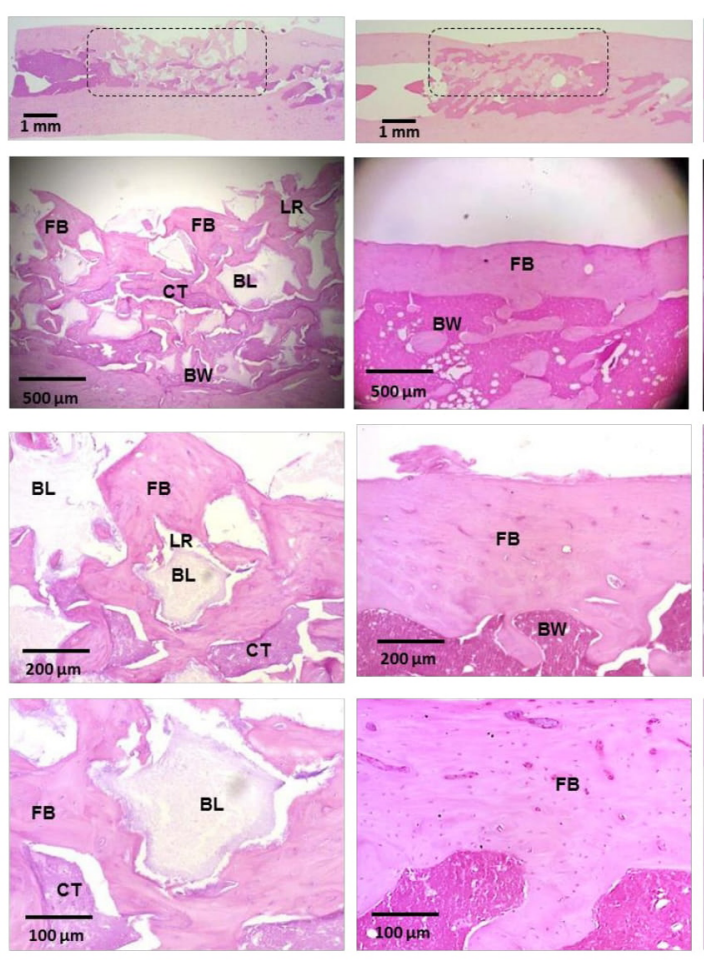
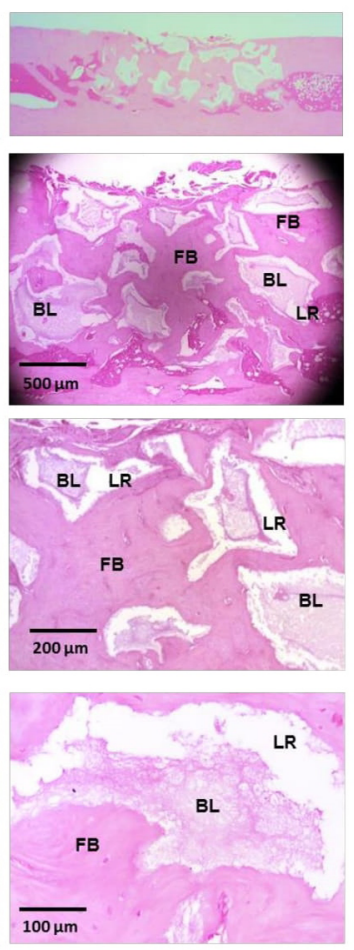

Figure 11. Representative images of histological sections stained with hematoxylin and eosin from the region of interest at 60 days after surgical procedure. LB: adjacent lamellar bone; FB: newly formed bone; BL: calcium phosphate biomaterial; RL: resorption lacunae; BW: bone marrow; CT: cellularized connective tissue. 

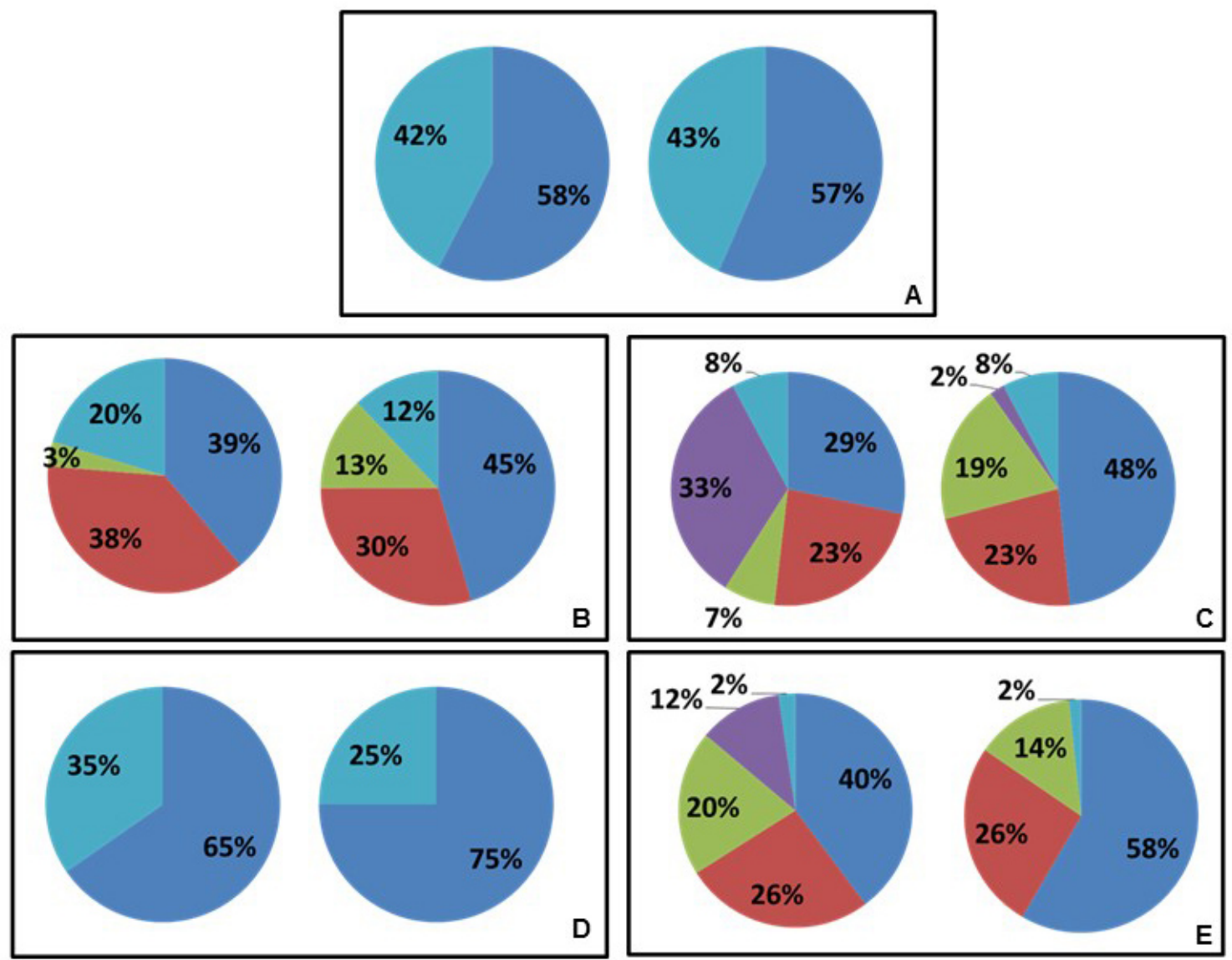

$\mathrm{FB}=\mathrm{BL} \equiv \mathrm{RL} \approx \mathrm{CT}=\mathrm{BW}$

Figure 12. Relative quantification of the defect site of all groups 30 and 60 days after procedure observed in histological sections. (A) Group 1 ; (B) Group 2 ; (C) Groups 3; (D) Group 4; (E) Group 5. FB: newly formed bone; BL: calcium phosphate material; RL: resorption lacunae; BW: bone marrow; CT: cellularized connective tissue.

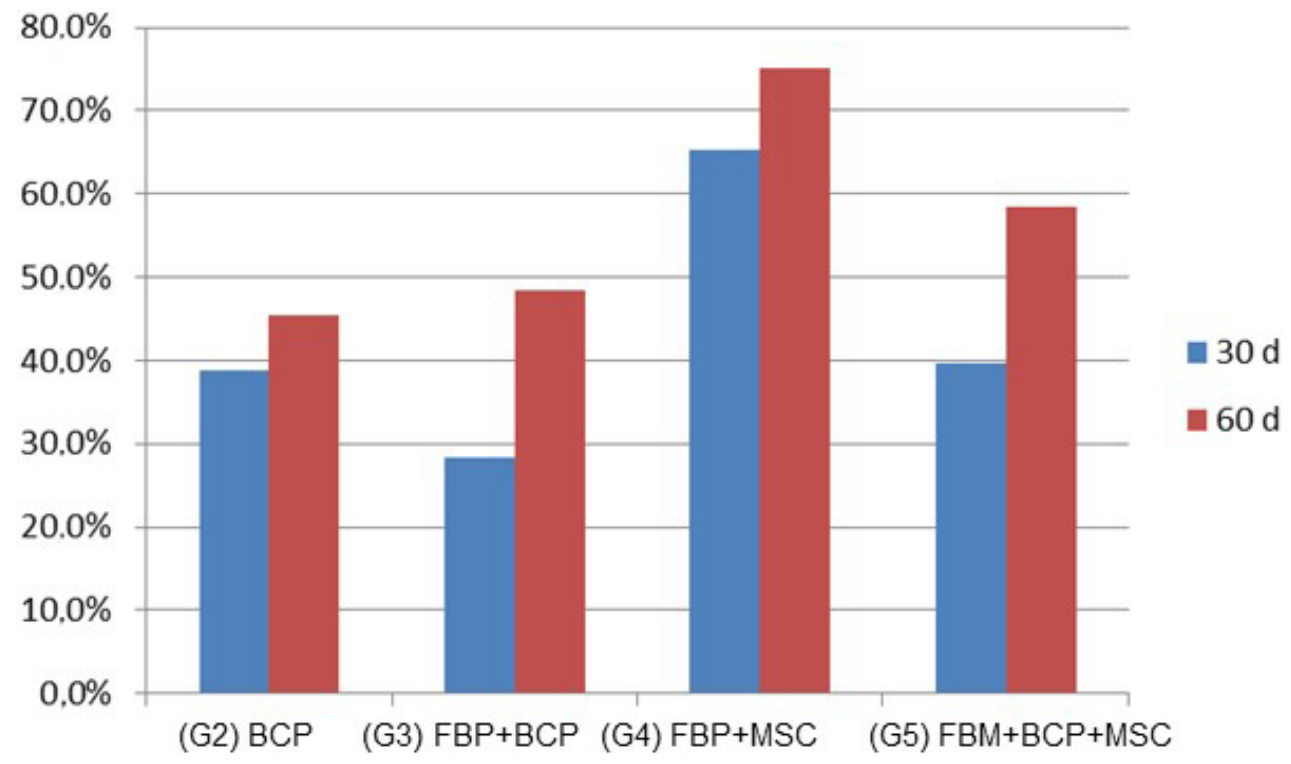

Figure 13. Relative quantification of progression of bone formation of treated groups 30 and 60 days after procedure observed in histological sections. 

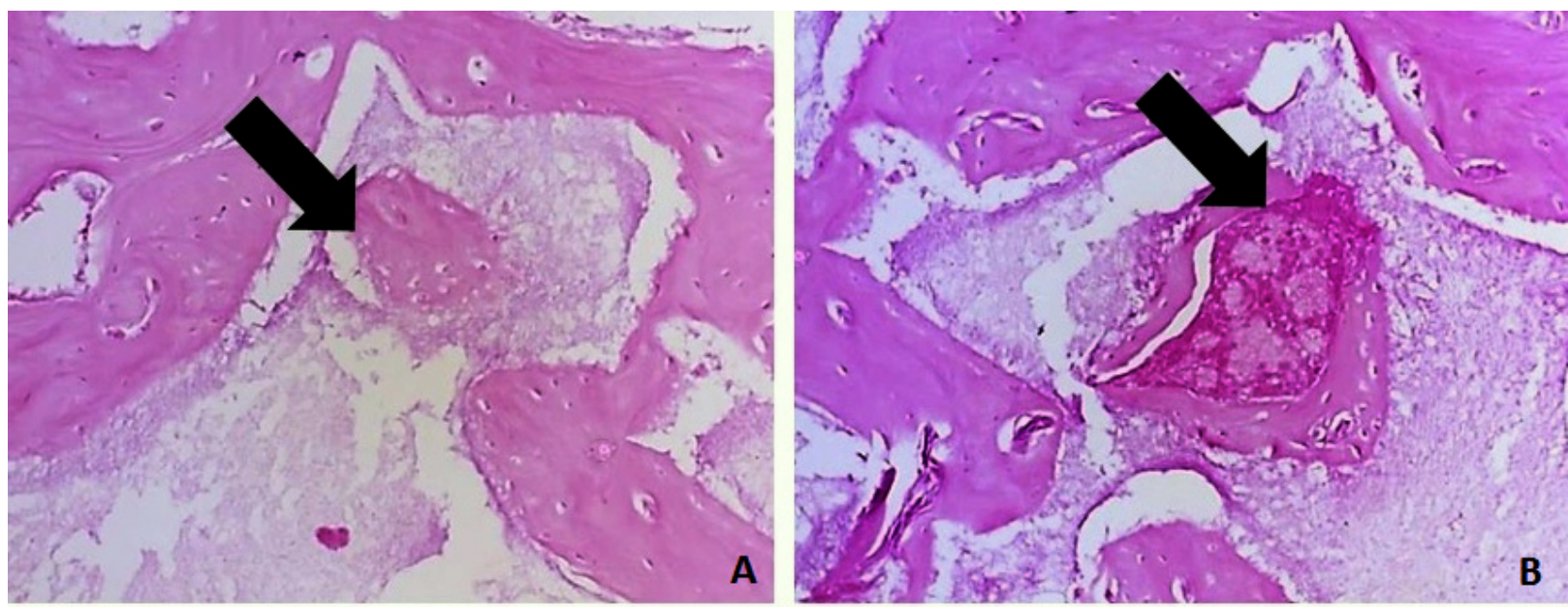

Figure 14. (A) and (B) Bone formation inside biphasic calcium phosphate granules at receptor site. Sections stained with hematoxylin and eosin.

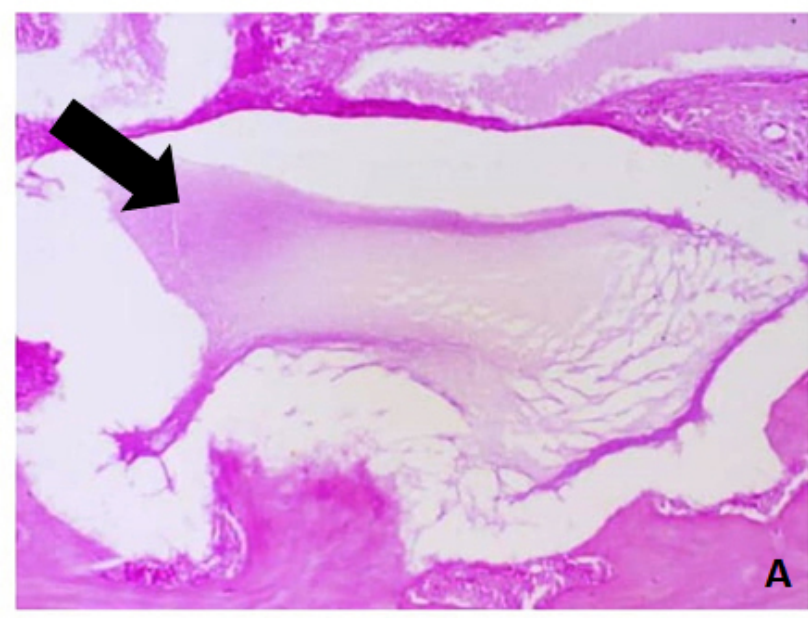

Figure 15. Progressive resorption of calcium phosphate granules at receptor site: and eosin.

The low cell proliferation inside calcium phosphate granules indicated slow granular reabsorption. The reabsorption of the material is dependent on variables such as particle size and porosity [83], and in the case of biphasic compounds, also on the proportion of its components [55]. The porosity of this material allows vascularization, diffusion of fluids and cell migration [84] and its gradual resorption by osteoclasts $[85,86]$. Bose et al. [87] recommend that the ideal particle diameter be between 200 and $350 \mu \mathrm{m}$. In the present study, the range of calcium phosphate porosity is 10 to $100 \mu \mathrm{m}$, which may have impeded the diffusion of liquids and the absorption of the material in the defect produced. The resorption rate is also influenced by particle size $[88,89]$. In cranial defects induced in rabbits, Kon et al. [90] found that particles of 150-400 $\mu \mathrm{m}$ showed adequate resorption proportional to the speed of bone remodeling, but offered little stability compared to $1.0-2.0 \mathrm{~mm}$ particles.

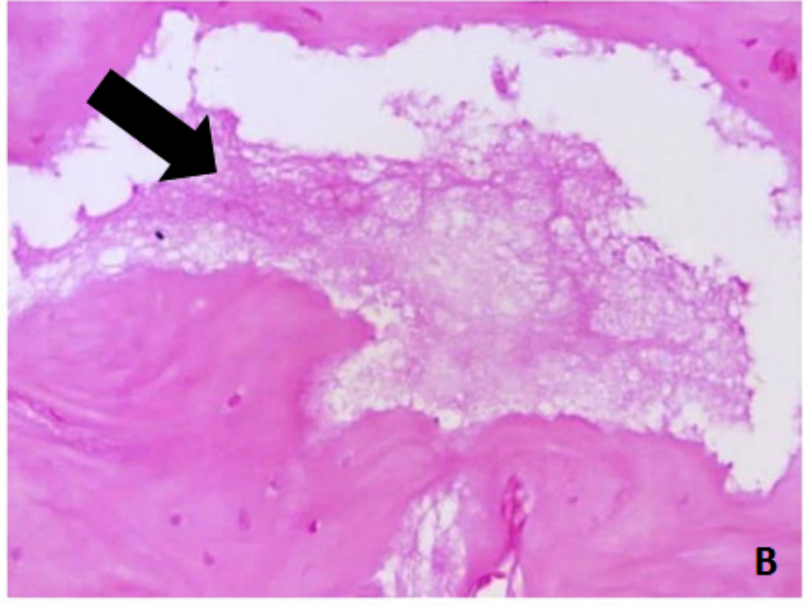

(A) 30 and (B) 60 days after implantation. Sections stained with hematoxylin

Thus, gradual resorption may not be totally negative where grafts need more stability and mechanical strength at the first moment of the remodeling process $[62,91]$. In these cases, the adding of fibrin biopolymer may improve the mechanical strength of the site, thus facilitating the incorporation of the graft into the injured area $[62,72,92]$. In view of these characteristics, a longer observation period is necessary to determine the efficacy of the association between FBP, calcium phosphate and MSC.

On the other hand, FBP was not visible 30 days after the implantation, which may indicate reabsorption proportional to the new bone formation. In accordance with the principle that an ideal biological framework should offer hemostasis and be degraded in the same proportion as new tissue is formed [47,93], FBP is a suitable scaffold candidate for bone repair.

We highlight that the groups in which phosphate and FBP were used, with or without addition of MSCs, presented at 
30 days a greater quantity of highly cellularized connective tissue. Gasparotto et al. [30] described the ability of the FBP to capture and maintain at its site the stem cells applied, due to the dense fibrin network formed. Studies have found that the presence of fibrin increased cell proliferation and recruitment of mesenchymal stem cells to such scaffolds [94]. However, due to the unique characteristics of this FBP, further analysis is required to elucidate cell behavior in the presence of this scaffold. Nevertheless, the bioactive characteristic of this compound was validated, in addition to the advantages of being a biodegradable scaffold [77] with good capacity to integrate with biologicals [42] or synthetic biomaterials [43] that do not present toxic or cytotoxic compounds [44] and show biocompatibility with bone tissue [41].

The highly satisfactory results obtained by the association of FBP with MSCs evidence the potential clinical candidate of this association. Sixty days after implantation, a mean of $70 \%$ of observed histological sections was occupied by formed bone. In the present study, no differentiation of MSCs into osteogenic lineage was performed, indicating that this process may not be required to achieve satisfactory bone repair, which could shorten the time between the collection and application of cells and, consequently, reduce the cost of cellular expansion.

Finally, further studies applying differentiated lineage of MSCs and longer observational periods (more than 60 days) are required to reinforce the obtained results.

\section{Conclusions}

All applied biomaterials are biocompatible and present good interaction with each other and the adjacent tissue, showing interfaces and osseointegration. Progressive bone matrix deposition was demonstrated in all treated groups, and was greater in the group that received FBP together with MSCs. FBP proved to be an excellent scaffold candidate in bone repair therapies due to its ease of application, biocompatibility, biodegradability and bioactive properties. The association has demonstrated satisfactory results, which may suggest a more effective and less costly approach for clinical applications in bone tissue engineering. Clinical trials will be necessary to prove this hypothesis.

\section{Abbreviations}

ANVISA: Brazilian Health Regulatory Agency; BCP: biphasic calcium phosphate; DMEM: Dulbecco's Modified Eagle Medium; FBP: fibrin biopolymer; HA: hydroxyapatite; HE: hematoxylin and eosin; MAC: minimum alveolar concentration; MSC: mesenchymal stem cell; PBS: phosphate-buffered saline; TCP: $\beta$-tricalcium phosphate.

\section{Acknowledgments}

The authors are grateful to Experimental Research Unity (UNIPEX), Department of Morphology of Botucatu Biosciences
Institute and Dr. Hélio Rubens de Carvalho Nunes from Research Support Office of FMB/UNESP, Botucatu.

\section{Availability of data and material}

The data generated and analyzed during the current study are available from the corresponding author upon reasonable request.

\section{Funding}

This project was supported by the Brazilian National Council for Scientific and Technological Development (CNPq), in partnership with the Ministry of Health of Brazil (Decit/ SCTIE/MS), proc. n. 563582/2010-3 and the Coordination for the Improvement of Higher Education Personnel (CAPES), Toxinology AUX-PE-1219/2011, proc. n. 23038.000823/201121. Moreover, this publication was supported in part by $\mathrm{CNPq}$ and CAPES through "Programa Editorial CNPq/CAPES" call n. 18/2018, grant n. 404770/2018-5.

\section{Competing interests}

Benedito Barraviera, Rui Seabra Ferreira Jr. and Claudia Vilalva Cassaro, authors of this article, are respectively editor-in-chief, associate and junior editors of Journal of Venomous Animals and Toxins including Tropical Diseases. They did not get involved in the peer review process of this manuscript.

\section{Author's contributions}

CVC performed the surgical procedures, euthanasia, acquisition and material processing, analysis and interpretation of data. LAJJ helped with histological preparation, processing and analysis. PRL assisted in stem cell isolation and expansion and surgical procedures. MAG analyzed data generated by flow cytometry of cultivated mesenchymal stem cells. NPB, MVC and ALRO contributed to standardization of scanning electron microscopy procedure. DPD performed micro-CT scan and image processing on specific softwares. EJP, RSFJ, and $\mathrm{BB}$ contributed to the design of the study, analysis and interpretation of data. All authors revised the manuscript to important intellectual content. All of the authors have read and approved the manuscript.

\section{Ethics approval and consent to participate}

This study was approved by the Animal Ethics Committee of Botucatu Medical School, São Paulo State University (UNESP), Brazil, protocol number 1164/2016.

\section{Consent for publication}

Not applicable.

\section{Supplementary material}

The following online material is available for this article: 
Additional file 1. Surface cell markers used on mesenchymal stem cell characterization by flow cytometry.

Additional file 2. Qualitative analysis of images obtained by computed tomography.

Additional file 3. Results of stereological analysis.

Additional file 4. Statistical analysis.

\section{References}

1. Dimitriou R, Jones E, McGonale D, Giannoudis P. Bone regeneration: Current concepts and future directions. BMC Med. 2011;9(1):3-10.

2. Khosla S, Westendorf JJ, Mödder UI. Concise review: Insights from normal bone remodeling and stem cell-based therapies for bone repair. Stem Cells. 2010;28(12):2124-8.

3. Parfitt AM. Skeletal heterogeneity and the purposes of bone remodeling: Implications for the understanding of osteoporosis. In Marcus R, Feldman D, Nelson D, Rosen C, editors. Fundamental of Osteoporosis. 1st ed. London: Academic Press; 2009.

4. Shrivats AR, McDermott MC, Hollinger JO. Bone tissue engineering: State of the union. Drug Discov Today. 2014;19(6)781-6.

5. Le Nihouannen D, Goyenvalle E, Aguado E, Pilet P, Bilban M, Daculsi G, et al. Hybrid composites of calcium phosphate granules, fibrin glue, and bone marrow for skeletal repair. J Biomed Mater Res A. 2007;81(2):399-408.

6. Liu $\mathrm{H}$, Shao $\mathrm{H}, \mathrm{Chen} \mathrm{F}$, Zheng $\mathrm{H}$. Effects of the granularity of raw materials on the hydration and hardening process of calcium phosphate cement. Biomaterials. 2003;24(23):4103-13.

7. Zhang J, Liu W, Schnitzler V, Tancret F, Bouler JM. Calcium phosphate cements for bone substitution: Chemistry, handling and mechanical properties. Acta Biomater. 2014;10(3):1035-49.

8. Le Guéhennec L, Layrolle P, Daculsi G. A review of bioceramics and fibrin sealant. Eur Cell Mater. 2004;13(8):1-10.

9. Gamblin AL, Brennan MA, Renaud A, Yagita H, Lézot F, Heymann D, et al. Bone tissue formation with human mesenchymal stem cells and biphasic calcium phosphate ceramics: The local implication of osteoclasts and macrophages. Biomaterials. 2014;35(36):9660-7.

10. Wang P, Zhao L, Liu J, Weir MD, Zhou X, Xu HH. Bone tissue engineering via nanostructured calcium phosphate biomaterials and stem cells. Bone Res. 2014;30(2):1-13.

11. Shih YRV, Hwanga YS, Phadkea A, Kanga H, Hwange NS, Caro EJ. Calcium phosphate-bearing matrices induce osteogenic differentiation of stem cells through adenosine signaling. Proc Natl Acad Sci. 2013;11(3):990-5.

12. Livingston TL, Gordon S, Archambault M, Kadiyala S, Mcintosh K, Smith A, et al. Mesenchymal stem cells combined with biphasic calcium ceramic phosphates promote bone regeneration. J Mater Sci Mater Med. 2003;14(3):211-8.

13. Müller $P$, Bulnheim $U$, Diener $A$, Lüthen $F$, Teller $M$, Klinkenberg ED, et al. Calcium phosphate surfaces promote osteogenic differentiation of mesenchymal stem cells. J Cell Mol Med. 2008;12(1):281-91.

14. Rastegar F, Shenaq D, Huang J, Zhang W, Zhang BQ, He BC, et al. Mesenchymal stem cells: Molecular characteristics and clinical applications. World J Stem Cells. 2010;2(4):67-80.

15. Long T, Zhu Z, Awad HA, Schwarz EM, Hilton MJ, Dong Y. The effect of mesenchymal stem cell sheets on structural allograft healing of critical sized femoral defects in mice. Biomaterials. 2014;35(9):2752-9.

16. O'Brien FJ. Biomaterials \& scaffolds for tissue engineering. Mater Today. 2011;14(3):88-95.

17. Stratton S, Shelke NB, Hoshino K, Rudraiah S, Kumbar SG. Bioactive polymeric scaffolds for tissue engineering. Bioact Mater. 2016;1(2):93-108.

18. Lee P, Trana K, Changa W, Fanga YL, Zhoua G, Junkaa R. Bioactive polymeric scaffolds for osteochondral tissue engineering: In vitro evaluation of the effect of culture media on bone marrow stromal cells. Polym Adv Tech. 2015;26(12):1476-85.

19. Lee $P$, Trana K, Changa W, Fanga YL, Zhoua G, Junkaa R. Bioactive polymeric scaffolds for osteochondral tissue engineering: In vitro evaluation of the effect of culture media on bone marrow stromal cells. Polym Adv Tech. 2015;26(12):1476-85.

20. Spotniz WD. Fibrin sealant: The only approved hemostat, sealant and adhesive- a laboratory and clinical perspective. ISRN Surg. 2014;203943:118.

21. Jackson MR. Fibrin sealants in surgical practice: An overview. Am J Surg. 2001;182(2):1S-7S.

22. Spotniz WD. Commercial fibrin sealants in surgical care. Am J Surg. 2001;182(2):8S-14S.

23. Hino $M$, Ishiko $O$, Honda $K$, Yamane $T$, Ohta $K$, Takubo $T$, et al. Transmission of symptomatic parvovirus B19 infection by fibrin sealant used during surgery. Br J Haematol. 2000;108(1):194-5.

24. Kawamura M, Sawafuji M, Watanabe M, Horinouchi H, Kobayashi K. Frequency of transmission of human parvovirus B19 infection by fibrin sealant used during thoracic surgery. Ann Thorac Surg. 2002;73(4):1098100.

25. Barros LC, Ferreira Junior RS, Barraviera SRCS, Stolf HO, ThomaziniSantos IA, Mendes-Giannini MJS, et al. A new fibrin sealant from Crotalus durissus terrificus venom: Applications in medicine. J Toxicol Environ Health Part B. 2009;12(8):553-71.

26. Ferreira Junior RS, de Barros LC, Abbade LPF, Barraviera SRCS, Silvares $M R C$, de Pontes LG, et al. Heterologous fibrin sealant derived from snake venom: From bench to bedside - an overview. J Venom Anim Toxins incl Trop Dis. 2017;23:21. doi: 10.1186/s40409-017-0109-8.

27. Ferreira AS, Barraviera B, Barraviera SR, Abbade LP, Caramori CA. A success in toxinology translational research in Brazil: Bridging the gap. Toxicon. 2013;69:50-4.

28. Abbade LPF, Barraviera SRCS, Silvares MRC, Carneiro MTR, Medolago NB, Ferreira Junior RS, et al. A new fibrin sealant derived from snake venom candidate to treat chronic venous ulcers. J Am Acad Dermatol. 2015;72:AB271.

29. Biscola NP, Cartarozzi LP, Benitez SU, Barbizan R, Castro MV, Spejo AB. Multiple uses of fibrin sealant for nervous system treatment followung injury and disease. J Venom Anim Toxins incl Trop Dis. 2017;23:13. doi: 10.1186/s40409-017-0103-1.

30. Gasparotto VPO, Landim-Alvarenga FC, Oliveira ALR, Simões GF, LimaNeto JF, Barraviera B, et al. A new fibrin sealant as a three-dimensional scaffold candidate for mesenchymal stem cells. Stem Cell Res Ther. 2014;5(3):78.

31. Biscola NP, Cartarozzi LP, Ferreira Junior RS, Barraviera B, Oliveira ALR. Long-standing motor and sensory recovery following acute fibrin sealant based neonatal sciatic nerve repair. Neural Plast. 2016;9028126:1-19.

32. Castro MV, Barbizan R, Ferreira Junior RS, Barraviera B, Oliveira ALR. Direct spinal ventral root repair following avulsion: Effectiveness of a new heterologous fibrin sealant on motoneuron survival and regeneration. Neural Plast. 2016;2932784:1-16.

33. Cartarozzi LP, Spejo AB, Ferreira Junior RS, Barraviera B, Duek E, Carvalho $J \mathrm{~L}$, et al. Mesenchymal stem cells engrafted in a fibrin scaffold stimulate Schwann cell reactivity and axonal regeneration following sciatic nerve tubulization. Brain Res Bull. 2015;112:14-24.

34. Barbizan R, Castro MV, Ferreira Junior RS, Barraviera B, Oliveira ALR. Influence of delivery method on neuroprotection by bone marrow mononuclear cell therapy following ventral root reimplantation with fibrin sealant. PLoS One. 2014;9(8):e105712.

35. Benitez SU, Barbizan R, Spejo AB, Ferreira RS Jr, Barraviera B, Góes AM, et al. Synaptic plasticity and sensory-motor improvement following fibrin sealant dorsal root reimplantation and mononuclear cell therapy. Front Neuroanat. 2014;9(8):1-16.

36. Barbizan R, Castro MV, Rodrigues AC, Barraviera B, Ferreira RS, Oliveira AL. Motor recovery and synaptic preservation after ventral root avulsion and repair with a fibrin sealant derived from snake venom. PLoS One. 2013;8(5):e63260. 
37. Buchaim RL, Andreo JC, Barraviera B, Ferreira Junior RS, Buchaim DV, Rosa Junior GM, et al. Effect of low-level laser therapy (LLLT) on peripheral nerve regeneration using fibrin glue derived from snake venom. Injury. 2015;46(4):655-60.

38. Rosso MPO, Rosa Júnior GM, Buchaim DV, German IJS, Pomini KT, de Souza RG, et al. Stimulation of morphofunctional repair of the facial nerve with photobiomodulation, using the end-to-side technique or a new heterologous fibrin sealant. J Photochem Photobiol B. 2017;175:20-8.

39. Buchaim DV, Rodrigues A de C, Buchaim RL, Barraviera B, Junior RS, Junior GM, et al. The new heterologous fibrin sealant in combination with low-level laser therapy (LLLT) in the repair of the buccal branch of the facial nerve. Lasers Med Sci. 2016;31(5):965-72.

40. de Barros CN, Miluzzi Yamada AL, Junior RS, Barraviera B, Hussni CA, de Souza JB, et al. A new heterologous fibrin sealant as a scaffold to cartilage repair-Experimental study and preliminary results. Exp Biol Med. 2016;241(13):1410-5.

41. Machado EG, Issa JP, Figueiredo FA, Santos GR, Galdeano EA, Alves MC. A new heterologous fibrin sealant as scaffold to recombinant human bone morphogenetic protein-2 (rhBMP-2) and natural latex proteins for the repair of tibial bone defects. Acta Histochem. 2015;117(3):288-96.

42. Gonçalves JBO, Buchaim DV, Bueno CRS, Pomini KT, Barraviera B, Ferreira Junior RS. Effects of low-level laser therapy on autogenous bone graft stabilized with a new heterologous fibrin sealant. J Photochem Photobiol B. 2016;162:663-8.

43. Cunha MR, Menezes FA, Santos GR, Pinto CAL, Barraviera B, Martins VCA. Hydroxiapatite and a new fibrin sealant derived from snake venom as a scaffold for treatment of cranial defects in rats. Mat Res. 2015;18(1):196203.

44. Iatecola A, Barraviera B, Ferreira Junior RS, dos Santos GR, Neves JI, da Cunha MR. Use of a new fibrin sealant and laser irradioation in the repair of skull defects in rats. Braz Dent J. 2013;24(5):456-61.

45. Orsi PR, Landim-Alvarenga FC, Justulin LA Jr, Kaneno R, de Assis Golim $M$, dos Santos DC, et al. A unique heterologous fibrin sealant (HFS) as a candidate biological scaffold for mesenchymal stem cells in osteoporotic rats. Stem Cell Res Ther. 2017;8(1):205.

46. Ryu JH, Kim IK, Cho SW, Cho MC, Hwang KK, Piao H, et al. Implantation of bone marrow mononuclear cells using injectable fibrin matrix enhances neovascularization in infarcted myocardium. Biomaterials. 2005;26(6):31926.

47. Bensaïd W, Triffitt JT, Blanchat C, Oudina K, Sedel L, Petite H. A biodegradable fibrin scaffold for mesenchymal stem cell transplantation. Biomaterials. 2003;24(14):2497-502.

48. LAS Brasil. Graftys -HBS. http://www.lasbrasil.com.br/graftys-hbsenxerto-osseo-2l.

49. Dominici M, Le Blanc K, Mueller I, Slaper-Cortenbach I, Marini F, Krause $D$, et al. Minimal criteria for defining multipotent mesenchymal stromal cells. The International Society for Cellular Therapy position statement. Cytotherapy. 2006;8(4):315-7.

50. CONCEA. Diretrizes da prática de eutanásia do CONCEA. Brasília: Ministério da ciência, tecnologia e inovação. 2013. http://www.fmb. unesp.br/Home/Pesquisa/ComissaodeEticaemExperimentacaoAnimal/ diretrizes-da-pratica-de-eutanasia-do-concea.pdf

51. Carpenter JW. Formulário de Animais Exóticos. 3rd ed. São Paulo: MedVet Ed; 2010

52. Thrall DE. Diagnóstico de Radiologia Veterinária. 6th ed. Rio de Janeiro: Elsevier Ed. 2015.

53. Weibel ER, Kistler GS, Scherle WF. Practical stereological methods for morphometric cytology. J Cell Biol. 1966;30:23-38.

54. Chamberlain G, Fox J, Ashton B, Middleton J. Concise review: mesenchymal stem cells: Their phenotype, differentiation capacity, immunological features, and potential for homing. Stem Cells. 2007;25(11):2739-49.

55. Arinzeh TL, Tran T, McAlary J, Daculsi G. A comparative study of biphasic calcium phosphate ceramics for human mesenchymal stem-cell-induced bone formation. Biomaterials. 2005;26(17):3631-8.

56. Jensen SS, Bornstein MM, Dard M, Bosshardt DD, Buser D. Comparative study of biphasic calcium phosphates with different HA/TCP ratios in mandibular bone defects: A long-term histomorphometric study in minipigs. J Biomed Mater Res B Appl Biomater. 2009;90(1):171-81.

57. Bagot D'Arc M, Daculsi G. Micro macroporous biphasic ceramics and fibrin sealant as a moldable material for bone reconstruction in chronic otitis media surgery. A 15 years experience. J Mater Sci Mater Med. 2003;14(3):229-33.

58. Franco-Vidal V, Daculsi G, Bagot d'Arc M, Sterkers O, Smail M, Robier A. Tolerance and osteointegration of Tric $\mathrm{S} / \mathrm{MBCP} \AA$ in association with fibrin sealant in mastoid obliteration after canal wall-down technique for cholesteatoma. Acta Otolaryngol. 2014;134(4):358-65.

59. Lee LT, Kwan PC, Chen YF, Wong YK. Comparison of the effectiveness of autologous fibrin glue and macroporous biphasic calcium phosphate as carriers in the osteogenesis process with or without mesenchymal stem cells. J Chin Med Assoc. 2008;71(2):66-73.

60. Durand M, Chauveaux D, Moinard M, Fabre T, Rouvillain JL, Bagot d'Arc $M$, et al. TricOs and fibrin sealant combined for bone defect filling: From pre-clinical tests to prospective clinical study. preliminary human data. Key Eng Mater. 2007;361(3):1335-8.

61. Dorozhkin SV, Epple M. Biological and medical significance of calcium phosphates. Angew Chem Int Ed Engl. 2002;41(17):3130-46.

62. Cui G, Li J, Lei W, Bi L, Tang P, Liang Y, et al. The mechanical and biological properties of an injectable calcium phosphate cement-fibrin glue composite for bone regeneration. J Biomed Mater Res B Appl Biomater. 2010;92(2):377-85.

63. Bouxsein ML, Boyd SK, Christiansen BA, Guldberg RE, Jepsen KJ, Müller R. Guidelines for assessment of bone microstructure in rodents using micro-computed tomography. J Bone Miner Res. 2010;25(7):1468-86.

64. Nyman JS, Munoz S, Jadhav S, Mansour A, Yoshii T, Mundy GR. Quantitative measures of femoral fracture repair in rats derived by micro-computed tomography. J Biomech. 2009;42(7):891-7.

65. Ramachandran M. Bone injury, healing and grafting. In: Bates P, Yeo A, Ramachandran M, editors. Basic Orthopaedics Sciences. 1st ed. Florida: CRC Press; 2006.

66. Dahlin C, Linde A, Gottlow J, Nyman S. Healing of bone defects by guided tissue regeneration. Plast Reconstr Surg. 1988;81(5):672-6.

67. Wang D, Tabassum A, Wu G, Deng L, Wismeijer D, Liu Y. Bone regeneration in critical-sized bone defect enhanced by introducing osteoinductivity to biphasic calcium phosphate granules. Clin Oral Implants Res. 2017;28(3):251-60.

68. França R, Samani TD, Bayade G, Yahia L, Sacher E. Nanoscale surface characterization of biphasic calcium phosphate, with comparisons to calcium hydroxyapatite and $\beta$ tricalcium phosphate bioceramics. J Colloid Interface Sci. 2014;420:182-8.

69. Chen TM, Tzeng YS, Tsai JC, Burnouf T. Single-donor allogeneic platelet fibrin glue and osteoconductive scaffold in orbital floor fracture reconstruction. Ann Plast Surg. 2013;70(3):370-4.

70. Yuan H, Fernandes H, Habibovic P, Boer J, Barradas AMC, Ruiter AD, et al. Osteoinductive ceramics as a synthetic alternative to autologous bone grafting. Proc Natl Acad Sci U S A. 2010;107(31):PMC2922269.

71. Kitayama S, Wong LO, Ma L, Hao J, Kasugai S, Lang NP, et al. Regeneration of rabbit calvarial defects using biphasic calcium phosphate and a strontium hydroxyapatite-containing collagen membrane. Clin Oral Implants Res. 2016;27(12):e206-14.

72. Beom-Su K, Sung HM, You HK, Lee J. Effects of fibrinogen concentration on fibrin glue and bone powder scaffolds in bone regeneration. J Biosci Bioeng. 2014;118(4):469-75.

73. Zhang Y, Yang S, Zhou W, Fu H, Qian L, Miron RJ. Addition of a synthetically fabricated osteoinductive biphasic calcium phosphate bone graft to BMP2 improves new bone formation. Clin Implant Dent Relat Res. 2016;18(6):1238-47.

74. Zou B, Chen X, Zhi W, Liu Y, Cui W, Hu S. Promoted healing of femoral defects with in situ grown fibrous composites of hydroxyapatite and poly(DL-lactide). J Biomed Mater Res A. 2012;100(6):1407-18.

75. Le Nihouannen D, Saffarzadeh A, Gauthier O, Moreau F, Pilet P, Spaethe $R$. Bone tissue formation in sheep muscles induced by a biphasic calcium phosphate ceramic and fibrin glue composite. J Mater Sci Mater Med. 2008;19(2):667-75. 
76. van Esterik FA, Zandieh-Doulabi B, Kleverlaan CJ, Klein-Nulend J. Enhanced osteogenic and vasculogenic differentiation potential of human adipose stem cells on biphasic calcium phosphate scaffolds in fibrin gels. Stem Cells Int. 2016;2016:1934270.

77. Yamada Y, Boo JS, Ozawa R, Nagasaka T, Okazaki Y, Hata K, et al. Bone regeneration following injection of mesenchymal stem cells and fibrin glue with a biodegradable scaffold. J Craniomaxillofac Surg. 2003;31(1):27-33

78. Kang SH, Chung YG, Oh IH, Kim YS, Min KO, Chung JY. Bone regeneration potential of allogeneic or autogeneic mesenchymal stem cells loaded onto cancellous bone granules in a rabbit radial defect model. Cell Tissue Res. 2014;355(1):81-8.

79. Hu J, Yang Z, Zhou Y, Liu Y, Li K, Lu H. Porous biphasic calcium phosphate ceramics coated with nano-hydroxyapatite and seeded with mesenchymal stem cells for reconstruction of radius segmental defects in rabbits. J Mater Sci Mater Med. 2015;26(11):246-57.

80. Le Nihouannen D, Guehennec LL, Rouillon T, Pilet P, Bilban M, Layrolle $\mathrm{P}$, et al. Micro-architecture of calcium phosphate granules and fibrin glue composites for bone tissue engineering. Biomaterials. 2006;27(13):271622.

81. Jegoux F, Goyenvalle E, Bagot D'arc M, Aguado E, Daculsi G. In vivo biological performance of composites combining micro-macroporous biphasic calcium phosphate granules and fibrin sealant. Arch Orthop Trauma Surg. 2005;125(3):153-9.

82. Hench LL. Bioactive materials: The potential for tissue regeneration. J Biomed Mater Res. 1998;41(4):511-8

83. Ebrahimi M, Botelho MG, Dorozhkin SV. Biphasic calcium phosphates bioceramics (HA/TCP): Concept, physicochemical properties and the impact of standardization of study protocols in biomaterials research. Mater Sci Eng C. 2016;71(1):1293-312.

84. Holzapfel BM, Reichert JC, Schantz JT, Gbureck U, Rackwitz L, Noth U, et al. How smart do biomaterials need to be? A translational science and clinical point of view. Adv Drug Deliv Rev. 2013;65(4):581-603.
85. Yamada S, Heymann D, Bouler JM, Daculsi G. Osteoclastic resorption of calcium phosphate ceramics with different hydroxyapatite/ $\beta$-tricalcium phosphate ratios. Biomaterials. 1997;18(15):1037-41.

86. Monteiro MM, Campos da Rocha NC, Rossi AM, de Almeida Soares G. Dissolution properties of calcium phosphate granules with different compositions in simulated body fluid. J Biomed Mater Res A. 2003;65(2):299-305.

87. Bose S, Roi M, Bandyopadhyay A. Recent advances in bone tissue engineering scaffolds. Trends Biotechnol. 2012;30(10):546-54.

88. Ginebra MP, Driessens FC, Planell JA. Effect of the particle size on the micro and nanostructural features of a calcium phosphate cement: $A$ kinetic analysis. Biomaterials. 2004;25(17):3453-62.

89. Malard O, Bouler JM, Guicheux J, Heymann D, Pilet P, Coquard C, et al. Influence of biphasic calcium phosphate granulometry on bone ingrowth, ceramic resorption, and inflammatory reactions: Preliminary in vitro and in vivo study. J Biomed Mater Res. 1999;46:103-11.

90. Kon K, Shiota M, Ozeki M, Yamashita Y, Kasugai S. Bone augmentation ability of autogenous bone graft particles with different sizes: A histological and micro-computed tomography study. Clin Oral Implants Res. 2009;20(11):1240-6.

91. Lopez-Heredia MA, Pattipeilohy J, Hsu S, Grykien M, van der Weijden $B$, Leeuwenburgh SC, et al. Bulk physicochemical, interconnectivity, and mechanical properties of calcium phosphate cements-fibrin glue composites for bone substitute applications. J Biomed Mater Res A. 2013;101(2):478-90.

92. Dong J, Cui G, Bi L, Li J, Lei W. The mechanical and biological studies of calcium phosphate cement-fibrin glue for bone reconstruction of rabbit femoral defects. Int J Nanomedicine. 2013;8:1317-24.

93. Calori GM, Mazza E, Colombo M, Ripamonti C. The use of bone-graft substitutes in large bone defects: Any specific needs? Injury. 2011;42(2):S56-63.

94. Huang Q, Goh JC, Hutmacher DW, Lee EH. In vivo mesenchymal cell recruitment by a scaffold loaded with transforming growth factor beta1 and the potential for in situ chondrogenesis. Tissue Eng. 2002;8(3):469-82. 